\title{
قته الأولويات
}

\section{(تمبيقّات شقمية معاصرة)}

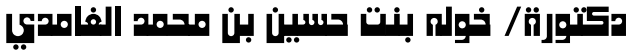

أستاذ الفقه المساعد بقسم الاراسات الإسلامية

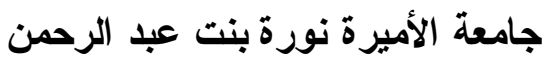

المستخلص باللغة العربية

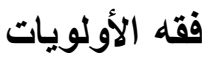

(تطبيقات فقهية معاصرة)

أهداف البحث: - إ:

1- الوصول إلى تعريف محدد يبين المر اد بــ(فقه الأولويات).

r- التأصيل الشرعي له.

r- بيان ضو ابطه.

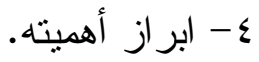

0- در اسة عدد من النطبيقات الفقهية المعاصرة لفقه الأولويات.

منهج البحث وإجر اءعاته:

اتبعت في هذا البحث المنهج الاستقر ائي و الاستتباطي، وكانت إجر اءاته كما يلي:

1- تحرير معنى فقه الأولويات، وتأصيله شر عًا.

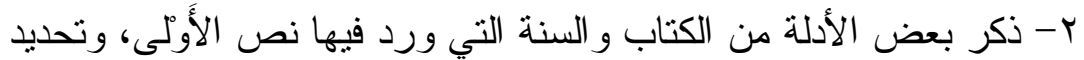

ضو ابط تلك الأولويات.

r- در اسة نماذج لتطبيقات فقهية معاصرة.

ع- عزو الآيات إلى موضعها من كتاب اله تعالى مع بيان اسم السورة، ورقم

الآية.

צ- تخريج الأحاديث من مصادر ها مع بيان درجتها عند المحدثين مالم تكن في

$$
\text { الصحيحين أو أحدهما. }
$$

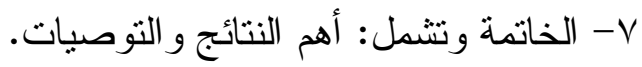




$$
\begin{aligned}
& \text { 1- فهرس المصادر • } \\
& \text { أولاً: النتائج: فرن }
\end{aligned}
$$

ا- الأحكام و التكاليف متفاوتة في الثرع تفاوتًا بليغاً، و الفهم الصحيح للشريعة

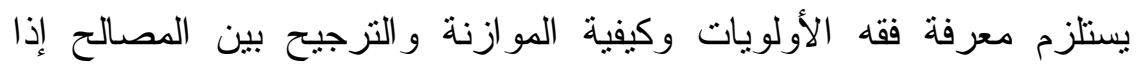
تعارضت، أو المفاسد إذا اجتمعت.

r- إن غياب فقه الأولويات من حياة الأمة يؤدي إلى مفاسد عظيمة.

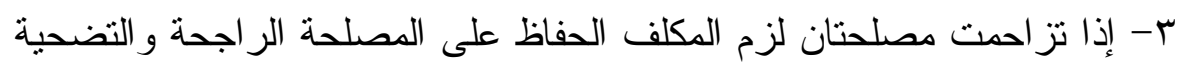
بالمصلحة المرجوحة، فيما إذا عجز عن الجمع بينهما.

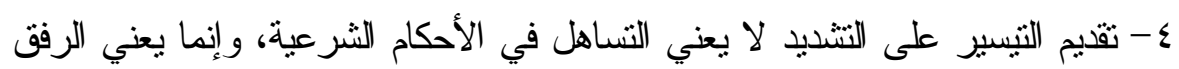
وعدم التكليف بما لا بطاق. ثانيًا: التوصيات:

1- توصي الباحثة الباحثين بالكتابة في بيان فقه الأولويات، لما له من الأهمية.

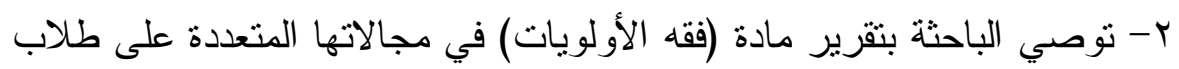
الجامعة، خاصة طلاب الدر اسات العليا. الكلمات الافتتاحية:

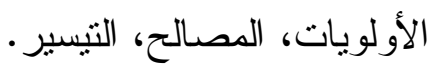




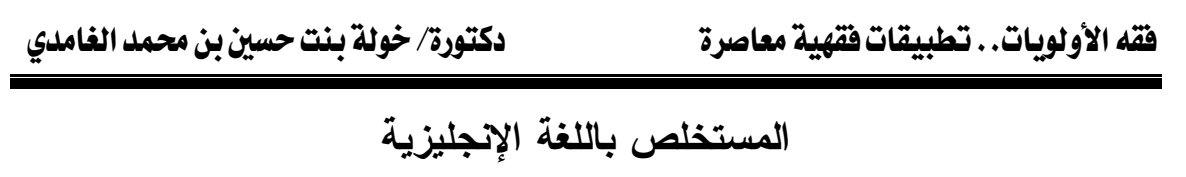

\section{In the Name of Allah the Beneficiary the Most Merciful \\ Jurisprudence of Priorities}

\section{Aims of the Research}

1- To define precisely the meaning of "Jurisprudence of priorities"

2- Its root in the Islamic Sharia Law.

3- Explain it controls

4- Show it importance

5- Study some contemporary jurisprudence applications of Jurisprudence of Priorities

\section{Methodology of the Research and its Procedures}

By the Will of Allah, I shall use both the inductive and deductive methodologies:

1- Compile, compose, and define the meaning of "Jurisprudence of Priorities" and prove its root in the Islamic Sharia.

2- Give some evidence from the Holy Quran and the Sayings of the Prophet and to determine the appropriateness of these priorities

3- Study some examples of the contemporary jurisprudence applications.

4- Attribute the Quranic Verses to their places in the Holy Quran together with the name of the Quranic Chapter and the No. of the Verse.

5- Documentation of Hadith from its original sources and explaining its Rank among Hadith Narrators and which of them is mentioned in Bukhari and Muslim Hadith Books (Al Sahihain) or whether it is mentioned in only one of them. 
6 -The Conclusion, it includes the most important findings and recommendations

7- Tables of indexes.

\section{First: the Findings:}

1- The provisions and obligations vary widely in Sharia, and the correct understanding of Shariah requires knowledge of jurisprudence of priorities and how to balance and weight between interests if they are inconsistent or if evil gathered together.

2-.If jurisprudence of priorities is absent in the life of the Nation "Ummah", then this will lead to great corruption.

3- If two interests came together, the designate shall preserve the outweighing interest and sacrifice the other interest, if he fails to combine them together.

4- If priority is given to the easier instead of the harder one "the rigid one" it does not mean leniency in the Sharia rulings, but rather it means making things easier for people and not assigning them what are unable to do.

\section{Second: Recommendations:}

1- The Researcher recommends that researchers shall carryout further research on the subject and write more about jurisprudence priorities, because of its importance.

2- The Researcher also recommends that (Jurisprudence priorities) and its various fields be taught as a course at the various universities to students, especially graduate students.

KEY Words:

Priorities, Interests, the easier 
المقدمة:

إن الحمد لله، نحمده ونستعينه، ونستغفره ونتوب إليه، ونعوذ باله من شرور

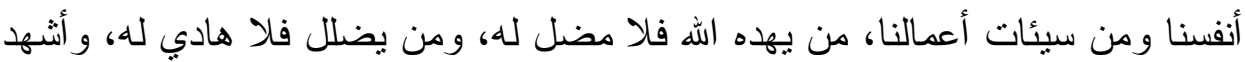
أن لا اله إلا الهه وحده لا شريك له، و أثنه أن محمدًا عبده ورسوله، صلهى الله عليه و على آله وصحبه وسلم تسليمًا كثير ا. الاه أما بعد:

فإن الشريعة مبناها على تحصيل المصالح وتكميلها، وتعطيل المفاسد وتقليلها

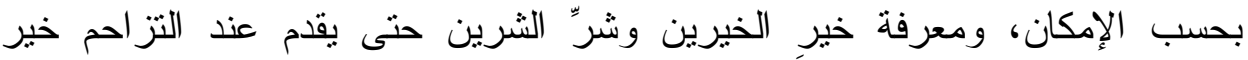

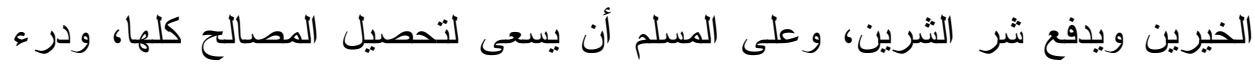
المفاسد جميعها، ولكن ذلك قد يتعذر في أحو ال كثيرة، فلا بتمكن المرء من تحقيق ولتيق

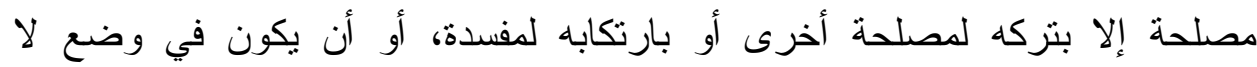
يستطيع أن يترك مفسدة إلا إذا ارتكب أخرى أو نرك مصلحة، فيلزمه أن يختار أخفهما

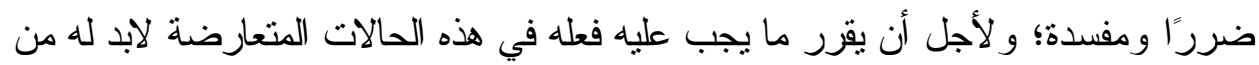

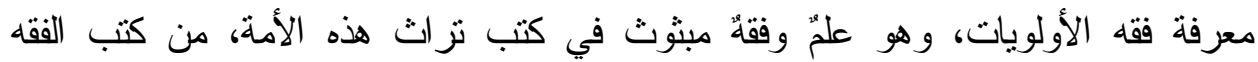
و الأصول والعقائد، وهو ما يعرف بفقه مراتب الأعمال، حيث يتعلم منه المسلم أن للأعمال

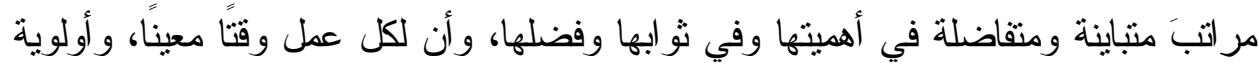
منقدمة على غيرها، فالفهم الصحيح للشريعة يسنلزم معرفة فقه الأولويات، وكيفية الموازنة

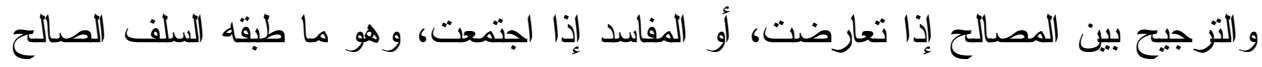
والأئة المجتهدون، وكبار علماء الإسلام وفقهاؤه بكل وعي وبصيرة، في جميع أبواب الفقه الإسلامي. ومن هنا تبرز الحاجة لدر اسة موضوع (ققه الأولويات) من خلال (تطبيقات فقهية

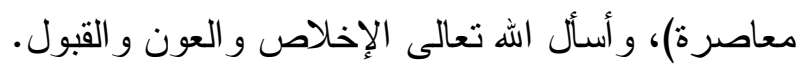
أهمية الموضوع وأسباب اختياره: 1- أن من الأهمية البالغة لكل مسلم أن ينضبط عنده ميزان الأولويات، حتى لا يقدِّم المهم على الأهم، أو يحرص على الئه المفضول ويترك الفاضل.

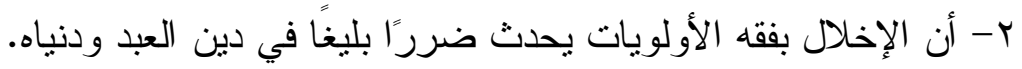


r- أن انضباط مبز ان الأولويات في حياة المسلمين في ظروفنا الراهنة بات ضرورة شرعية،

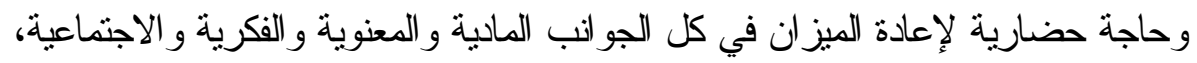

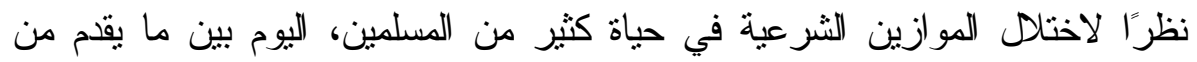
الأحكام وما يؤخر، وبين المهر منها والأهم، وبين الفاضل والمفضول، وبين الصالح

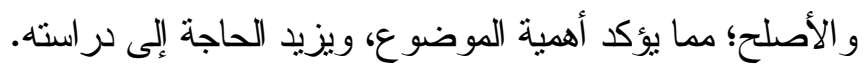

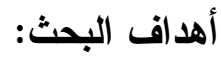

1- الوصول إلى تعريف محدد يبين المراد بــ(فقه الأولويات). r- التأصيل الثرعي لفقه الأولويات. ب- بيان ضو ابط فقه الأولويات. ع- إبر از أهمية فقه الأولويات.

0- در اسة عدد من النطبيقات الفقهية المعاصرة لفقه الأولويات.

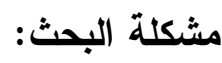
يمكن إجمال التساؤلات في الموضوع في الآتي: - ما المر اد بفقه الأولويات؟ العمال

- هل لهذا الفقه أصل شرعيّ في الكتاب و السنة؟ الاوله - ما مدى أهمية هذا العلم؟ وما الآثار المترتبة على الإخلال بهل به؟

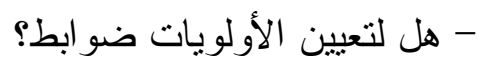

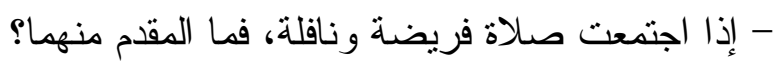

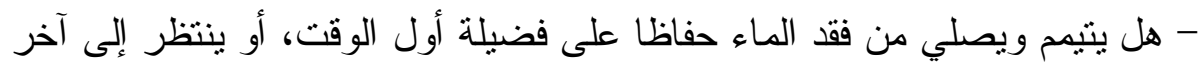
الوقت؛ ليدرك فرض الطهارة ولته

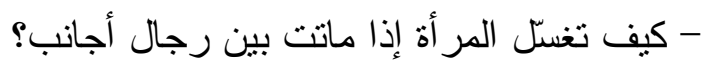
- من الأولى بحضانة البنت بعد سبع سنين؟ - من كثر منه الثك في الصلاة حتى صلار وسو استًا، فهل يؤمر بسجود السهو و الإتبان بما شك فيه؟ الار اسات السابقة:

هنالك وجهة قديمة في التأليف قريبة من وجهة الأولويات، اهتم أصحابها بجمع الأو ائل في شتى أبو اب العلم، من عبادات وتاريخ، وجهاد وأسماء، و ألقاب و أمثال، أو أو 
في الوقائع و الأحداث... و غير ها، وكل هذه الدر اسات صلتها بموضوع البحث بعيدة. ومن الار اسات الحديثة:

• كتاب فقه الأولويات دراسة في الضوابط. تأليف د. محمد الوكيلي وكان محور الدر اسة هو ضو ابط فقه الأولويات.

• كما يوجد عدد من الأبحاث التي تحدثت عن فقه الأولويات بشيء من الإيجاز .

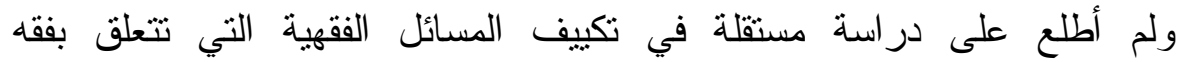
الأولويات.

\section{منهج البحث:}

بحول الله وقوته سوف أتبع المنهج الاستقرائي والاستنباطي، حيث أستقرئ

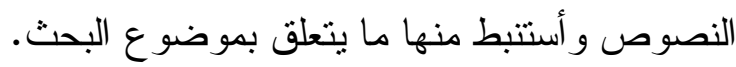

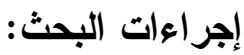

1 - تحرير معنى فقه الأولويات، وتأصيله شرعًا. r- ذكر بعض الأدلة من الكتاب و السنة التي ورد فيها نص الأولى أو ما بر ادفه من من فئه معان، وتحديد ضو ابط تللك الأولويات.

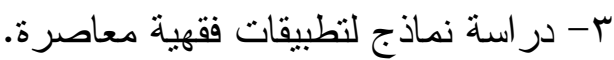
ع - عزو الآيات إلى موضعها من كتاب الله تعالى، مع بيان اسم السورة ورقم الآية.

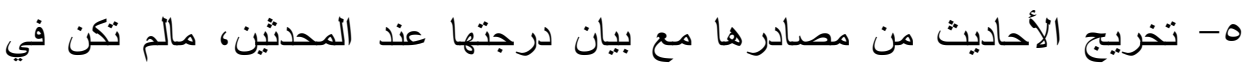

$$
\text { الصحيحين أو أحدهما. }
$$

ج- تذييل البحث بخاتمة نشنمل على أهم نتائح البحث وتوصياته، مع الفهارس اللازمة.

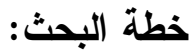
المقدمة: وتثنتمل على: أهمية الموضوع و أسباب اختياره، وأهداف البحث، ومشكلة البحث، و الدراسات السابقة، ومنهج البحث، وخطة البحث. الفصل الأول: وفيه أربعة مباحث: المبحث الأول: بيان المر اد بفقه الأولويات، وفيه مباديه مطلبان: المطلب الأول: فقه الأولويات باعتباره مركبًا. المطلب الثاني: تعريف فقه الأولويات باعتباره لقبًا. 
المبحث الثاني: أهمية فقه الأولويات.

المبحث الثالث: التأصيل الثرعي لفقه الأولويات، وفيه الأبله مطلبان:

المطلب الأول: الاستدلال من القرآن الكريم على مر اعاة الأولويات.

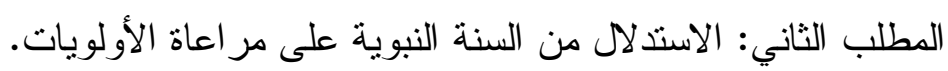

المبحث الر ابع: ضو ابط فقه الأولويات.

الفصل الثاني: التكييف الفقهي لمسائل تتعلق بفقه الأولويات، وفيه خمسة مباحث:

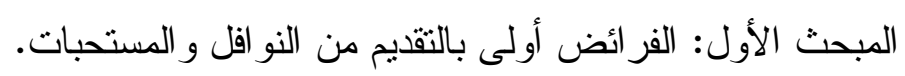

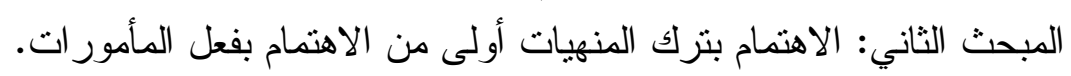

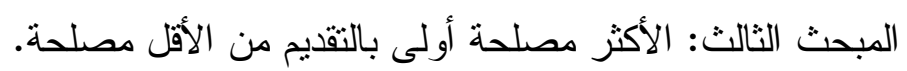

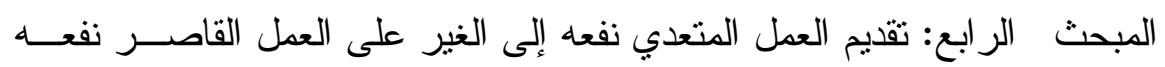

$$
\text { على صاحبه أولى. }
$$

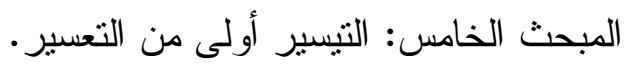

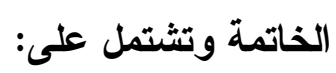

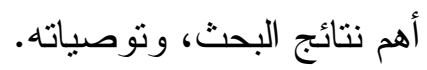

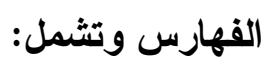

فهرس الآيات، وفهرس الأحاديث، وفهرس المصادر و المراجع، وفهرس الموضوعات. 


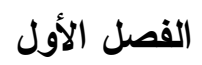

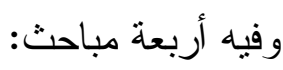

المبحث الأول: بيان المر اد بفقه الأولويات:

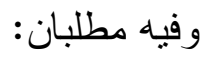

المطلب الأول: تعريف فقه الأولويات باعتباره مركبًا:

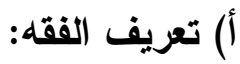

تعريف الفقه لغة:

كلمة الفقه مكونة من (الفاء و القاف و الهاء)، و "هي تدل على إدر الك الثنيء و العلم

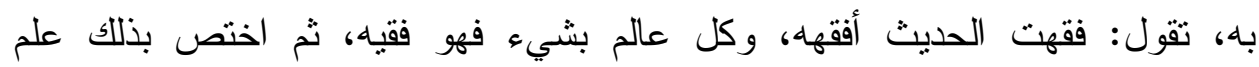

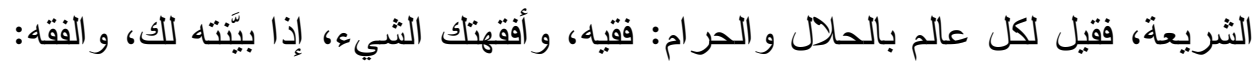

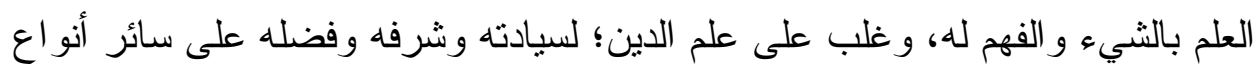

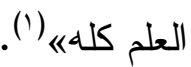

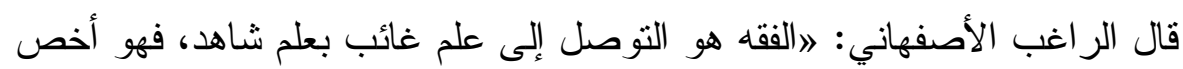

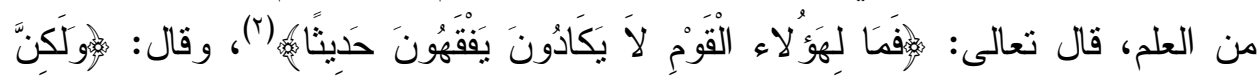

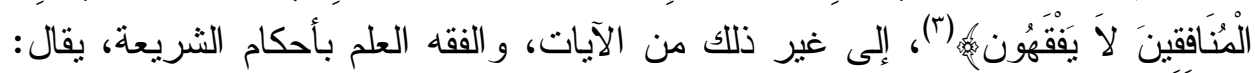

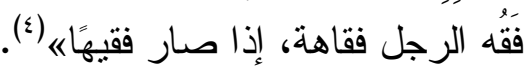
تعريف الفقه اصطلاحًا:

》الفقه هو معرفة الأحكام الثرعية العملية الدكنسبة من أدلتها التفصيليةه(0)

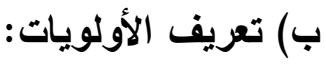

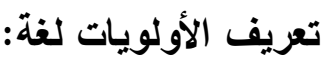
الأولويات جمع مفرده (أولى)، وهو اسم تفضيل، ويأتي لغة بمعنيين، الأول بمعنى

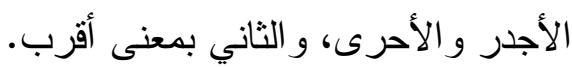

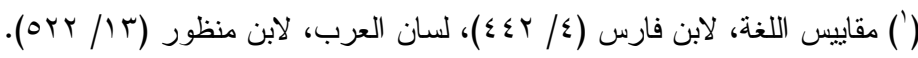

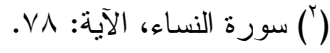

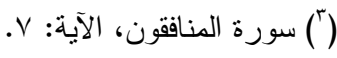

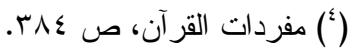

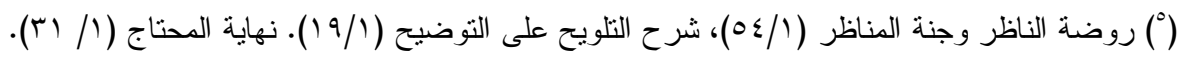


ولمادة (أولى) استعمالات أُخرَ، لكنها لا تخرج في مجمو عها عن المعنى الأصلي

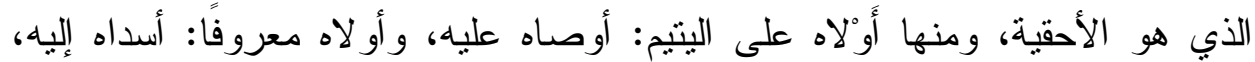

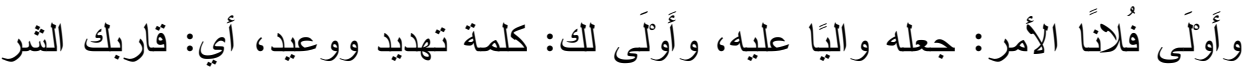
فاحذر .

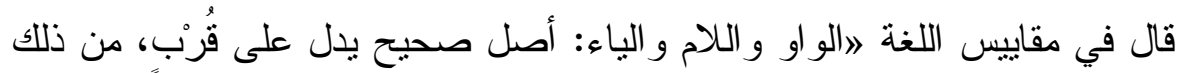

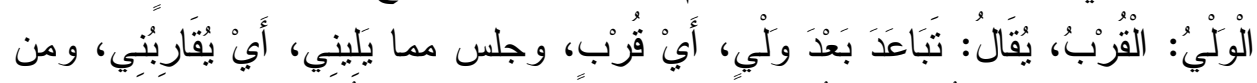

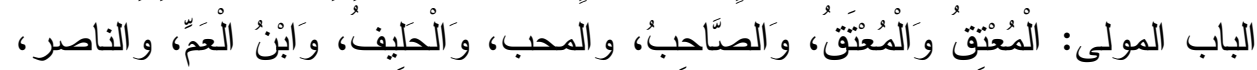

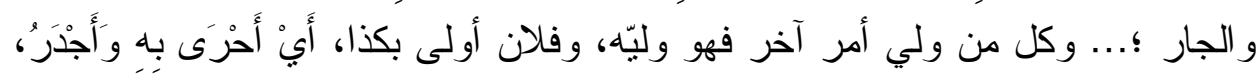

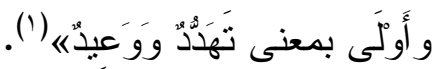
تعريف الأولويات اصطلاحًا: إن مصطلح الأولويات من المفردات المستخدمة في ترانثا الفكري، حيث استعمله

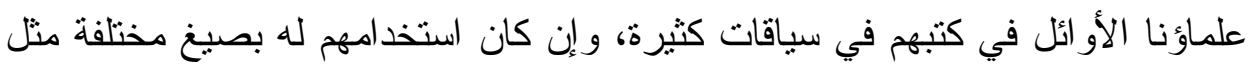

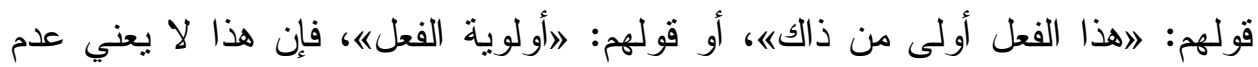

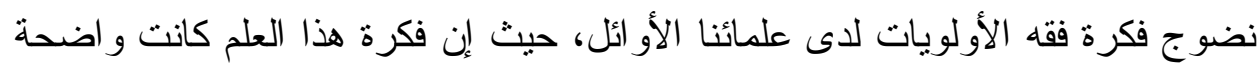

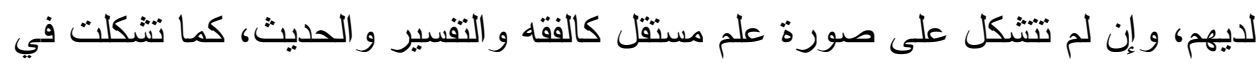

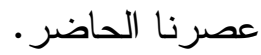
وكثر استخدام هذا المصطلح في العصر الحاضر، ولم يتعرض كثير منهم

لتعريفه؛ ولعل ذلك يعود إلى وضوح المصطلح، فالمعنى المتبادر منه يفهم بداهة (؟).

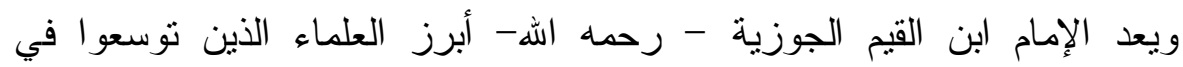

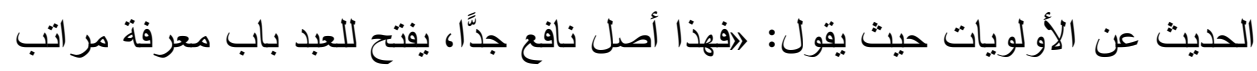

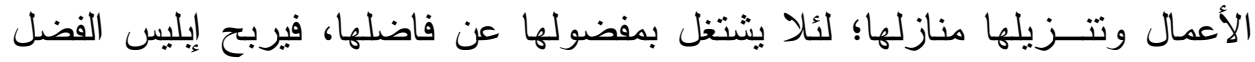
الذي بينهما، أو ينظر إلى فاضلها، فيشتخل به عن مفضولها إن كان ذلك وقته، فتفوته بله

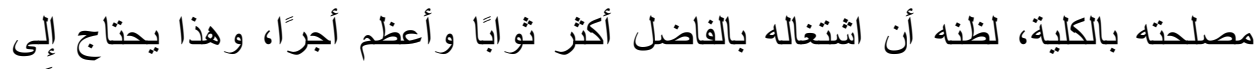
معرفة بمراتب الأعمال وتفاوتها ومقاصدها، وفقه في إعطاء كل عمل منها حقَّه،

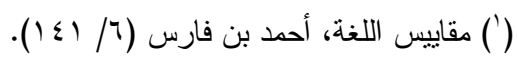

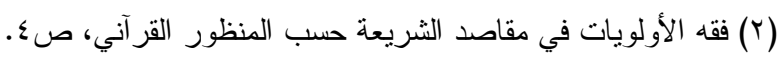


وتتـزله في مرتبته، وتفويته لما هو أهم منه، أو تفويت ما هو أولى منها ('). وفي العصر الحديث أصبح مصطلح الأولويات شائعَ الاستخدام بين أوساط العلماء الهاء و المفكرين الإسلاميّين.

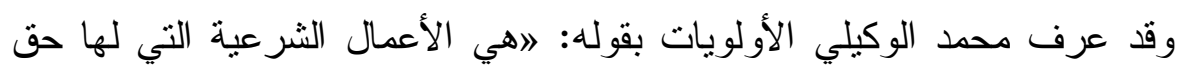

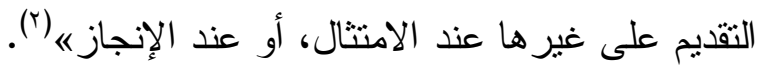

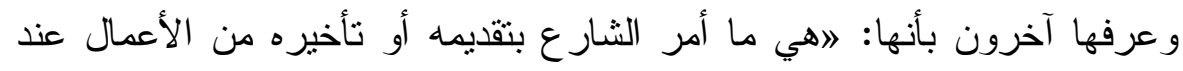

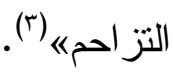
المطلب الثاني: تعريف فقه الأولويات باعتباره لقبًا:

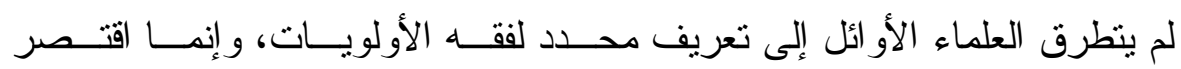

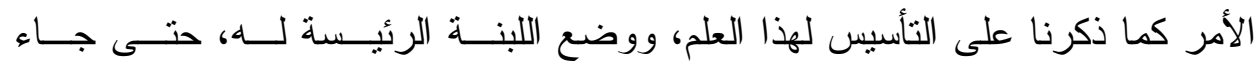

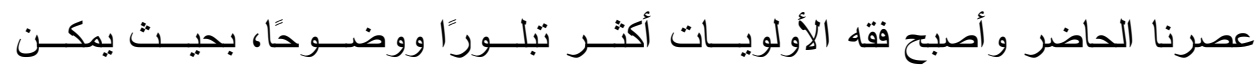

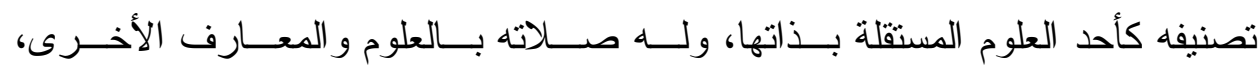

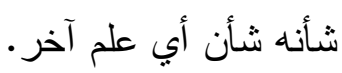
ويمكن تعريفه بأنه: العلم بالأحكام الثرعية التي لها حق التقديم على غيرها، بناء

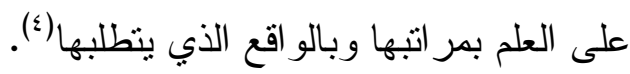
المبحث الثاني: أهمية فقه الأولويات: لفقه الأولويات أهمية بالغة أثنير إليها في النقاط الاولتابه التالية:

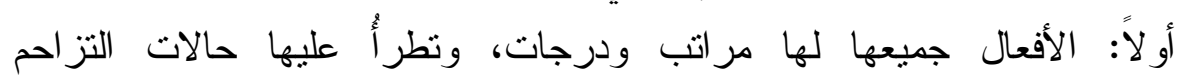

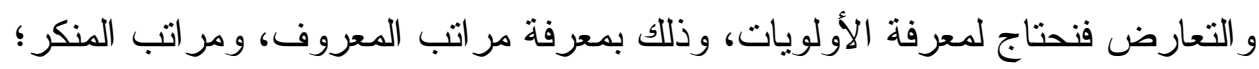
حتى نقدم الأهم على المهم. ثانيا: أن الأحكام و الأعمال و التكاليف متفاوتة في نظر الثر ع تفاوتًا بليغا، وليست

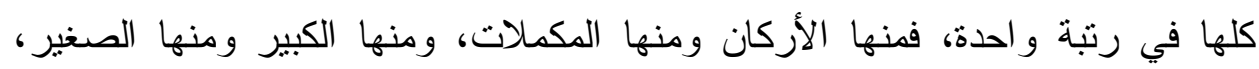

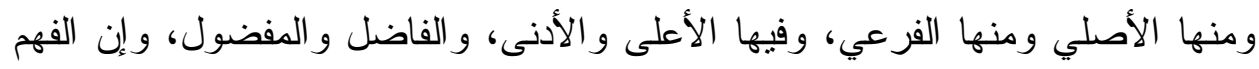

(1) الو ابل الصيب من الكلم الطيب، ص بو (1)

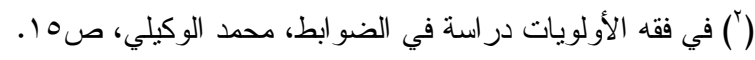

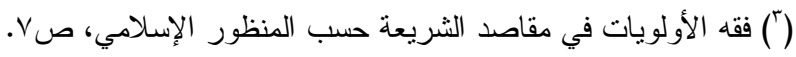

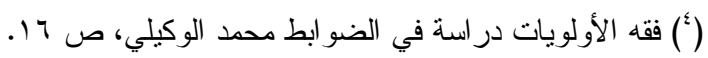


الصحيح للشريعة بستلزم معرفة فقه الأولويات، وكيفية الموازنة و الترجيح بين المصالح

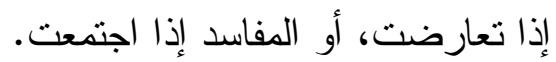
ثالثًا: أن الإخلاد بفقه الأولويات يحدث ضررًا بليغًا بالدين والحياة، فإن العقيدة

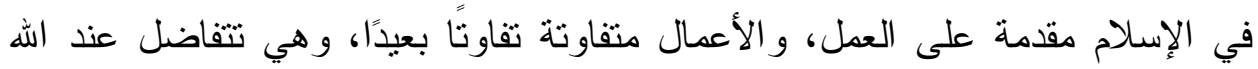
سبحانه.

رابعًا: أن انضباط ميزان الأولويات في حياة المسلمين في ظروفنا الراهنة بات

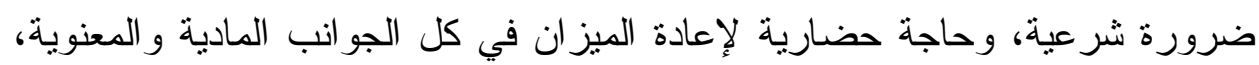
و الفكرية والاجتماعية، فالعلم به يدعونا لترتيب الأعمال، وبيان ما يجب فئ أن يقدم ويؤخر، وما هو واجب وما هو مستحب، وأيها محرّم، و أيها يستحق الاهتمام وبذل ولئل

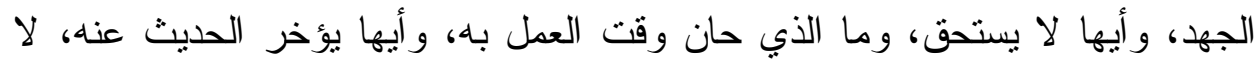

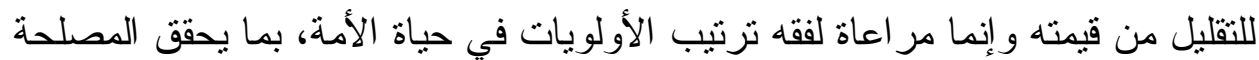

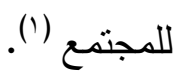
المبحث الثالث: التأصيل الثرعي لفقه الأولويات: وفيه مطلبان:

المطلب الأول: الاستدلال من القرآن الكريم على مراعاة الأولويات:

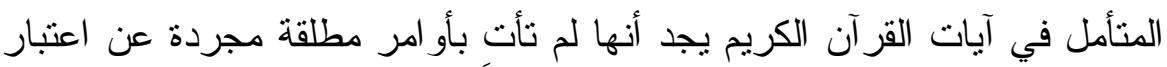

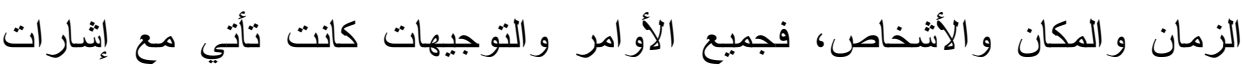
و اضحة إلى اعتبار ظروف التطبيق، وتثرير البديل الذي يتتاسب مع حال المكلفّ،

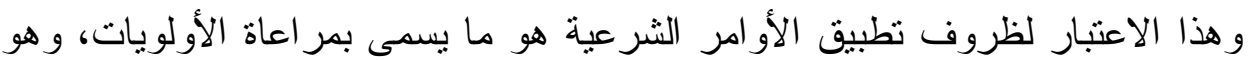

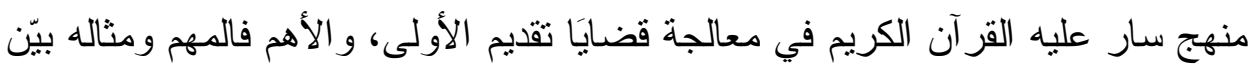
في المحافظة على الضروريات، ثم الانتقال إلى تحقيق الحاجيات، فالتحسينات .

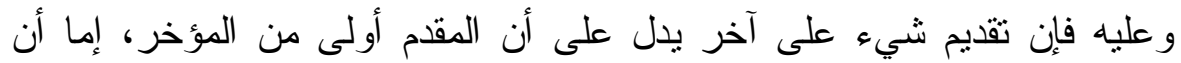

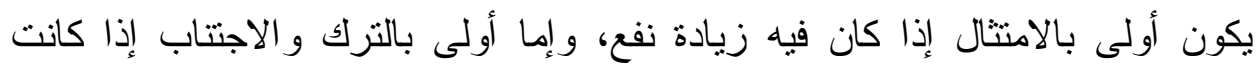
الزيادة ضررًا.

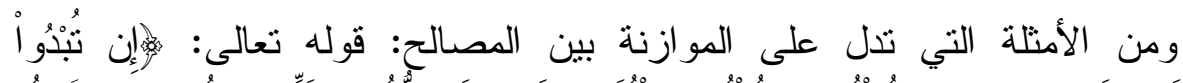

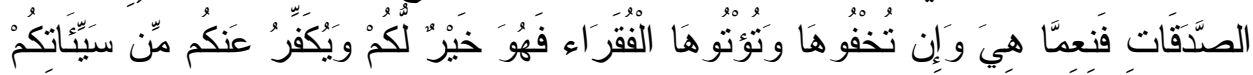




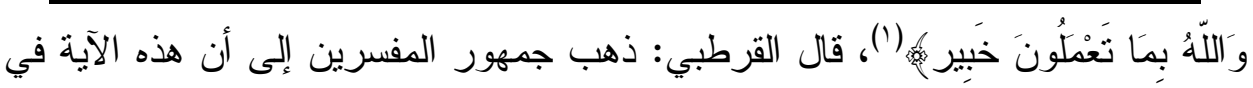

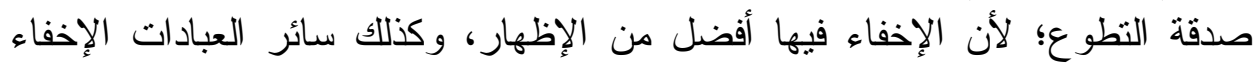

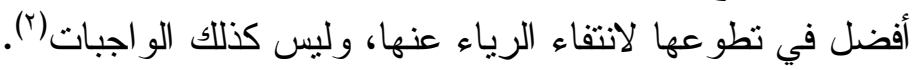

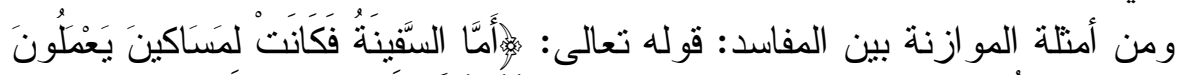

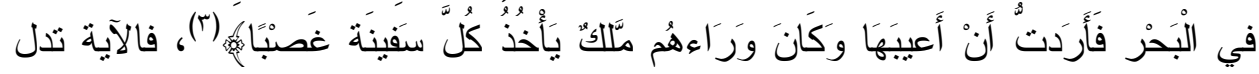

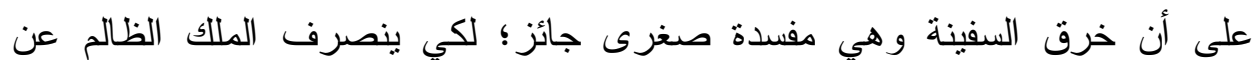

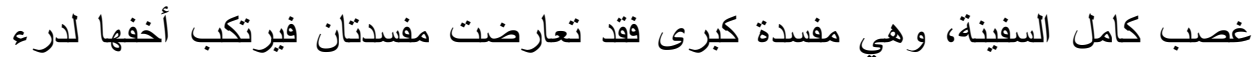

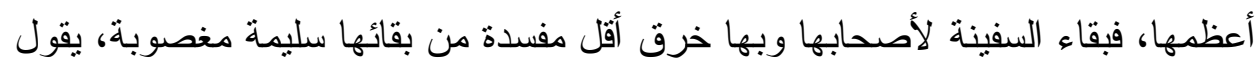

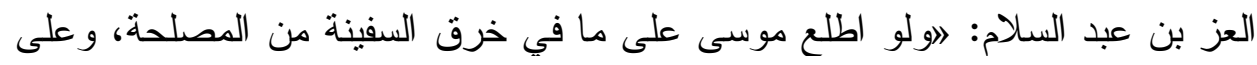

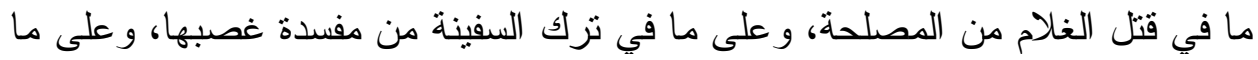

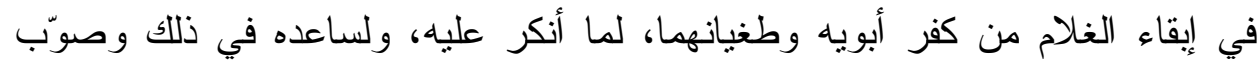

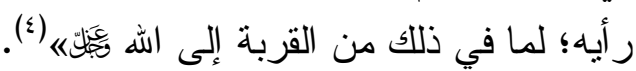
قال القرطبي: ففي هذا من الفقه العمل بالدصالح إذا تحقق وجهها، وجواز إلها إصلاح

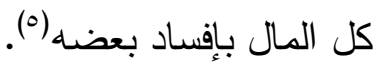

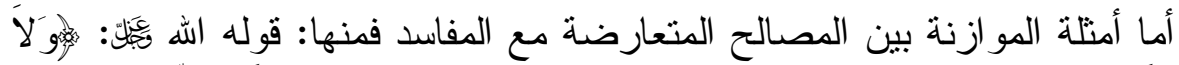

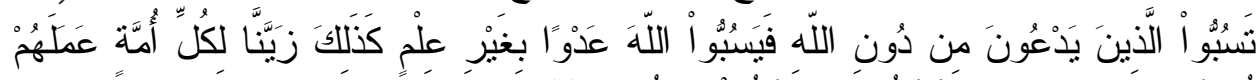

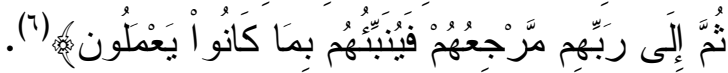

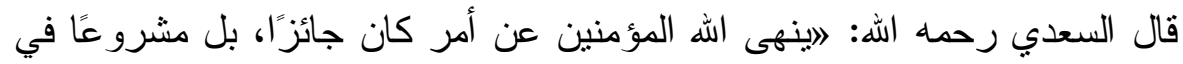

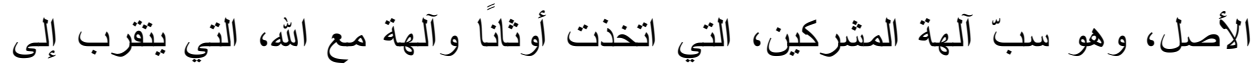
الله بإهانتها وسبها.

ولكن لما كان هذا السب طريقًا إلى سب المشركين لرب العالمين، الذي يجب

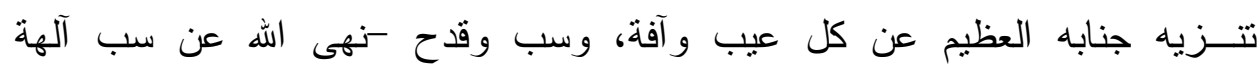

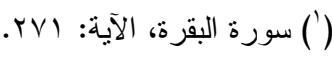

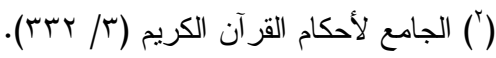

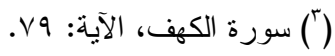

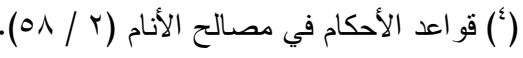

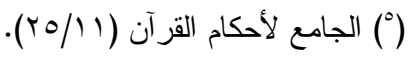

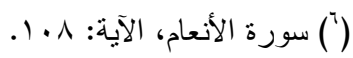


المشركين؛، لأنهم يحمون لدينهم، ويتعصبون له؛ لأن كل أمة زين اله لهم عملهم فر أوه

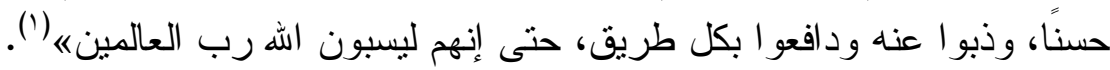
المطلب الثاني: الاستدلال من السنة النبوية على مراعاة الأولويات:

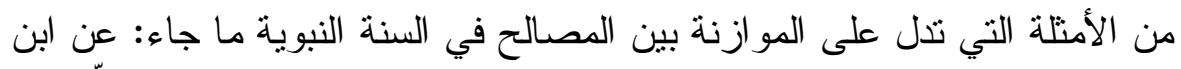

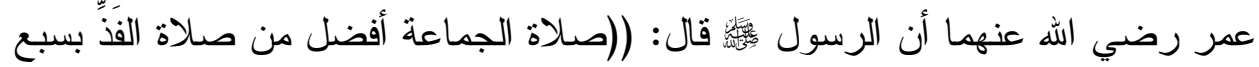
و عشرين درجة))، رو اه البخاري ومسلم (؟).

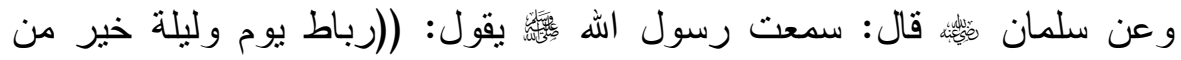
صيام شهر وقيامه))، رو اه مسلم (r).

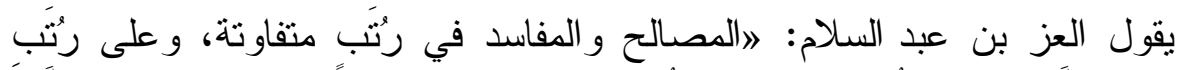

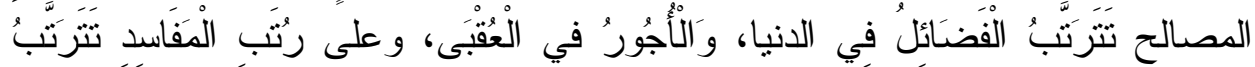

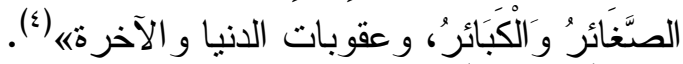

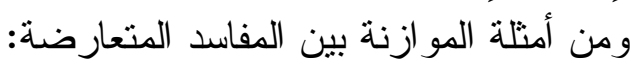

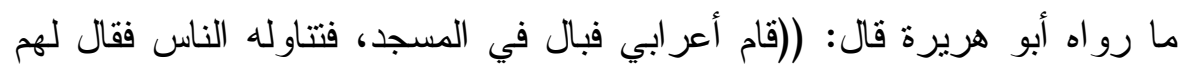

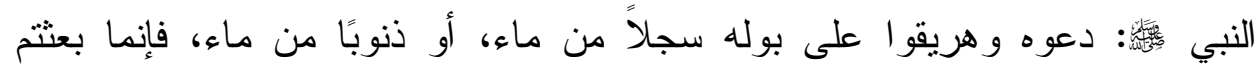

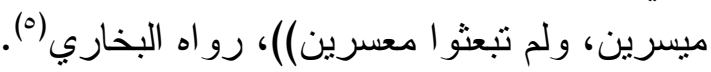

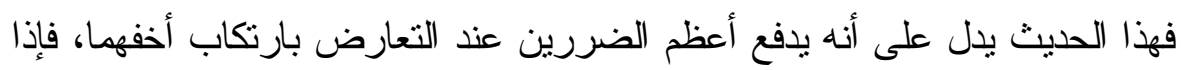
تعارضت مفسدتان أو أكثر فإنها تدفع أعظمها، وذلك بارتكاب أخفهما، ففي هذا الحديث

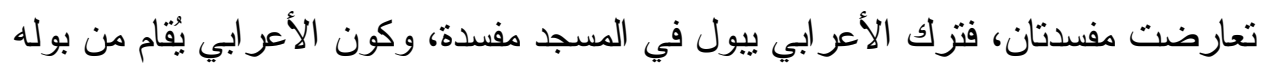

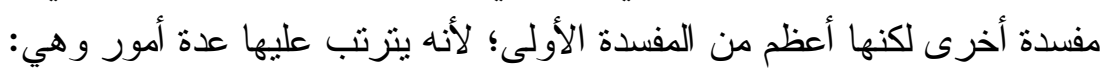

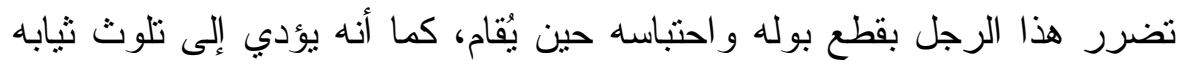
وبدنه، ويؤدي إلى تلوث مكان أكبر في المسجد، فمجموع هذه الأمور تبيّن عََّّ مفسدة

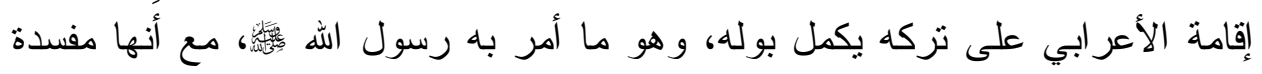

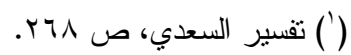

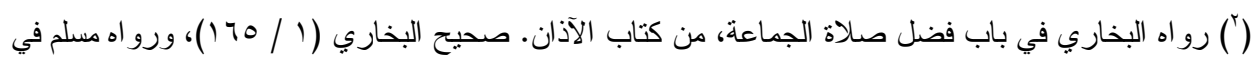

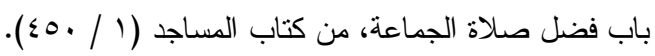

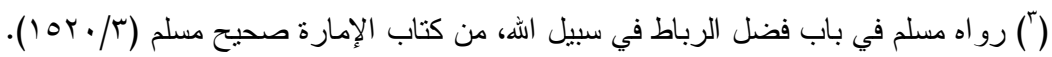

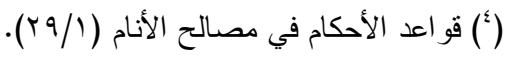

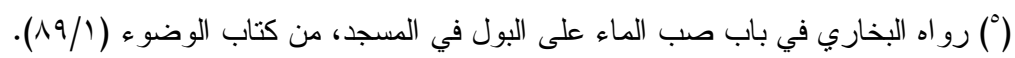


لكنها أخف من الأخرى، ومن أمنلة ما جاء في السنة من الموازنة بين المصالح

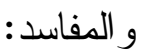

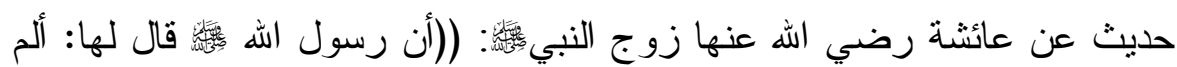

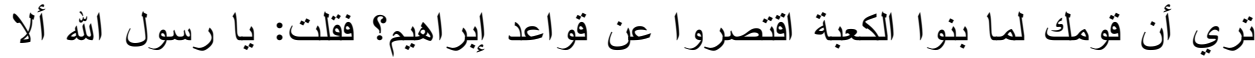

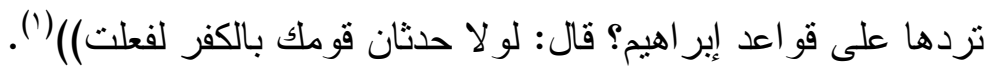

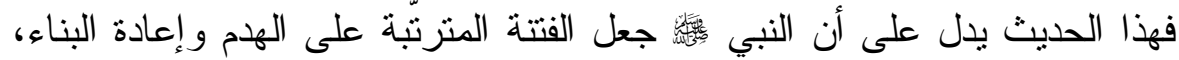

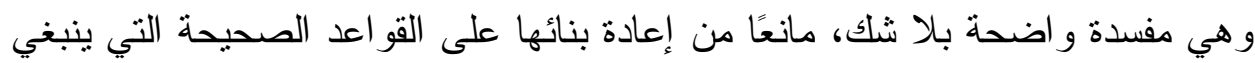
أن تبنى عليها، وهي المصلحة المقصودة في الحديث. يقول الإمام النووي: "افي هذا الحديث دليلّ على جملة من القو اعد و الأحكام منها:

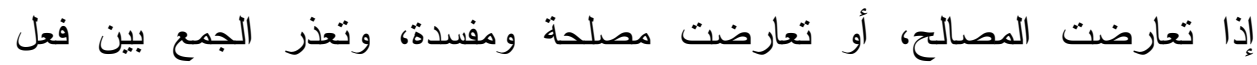

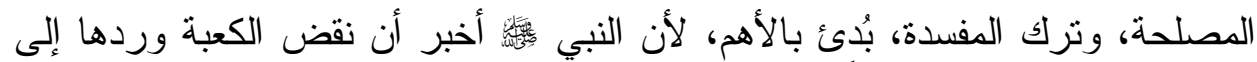

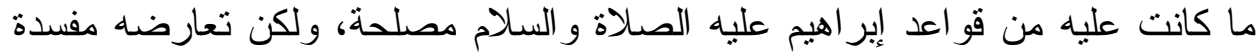

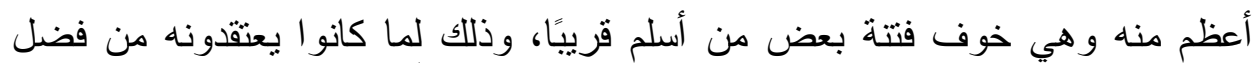

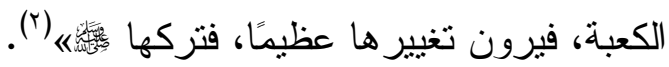

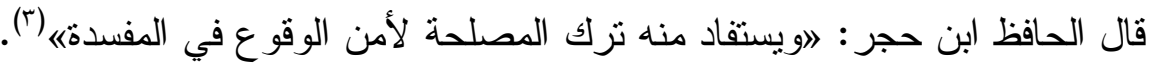
المبحث الر ابع: ضوابط فقه الأولويات:

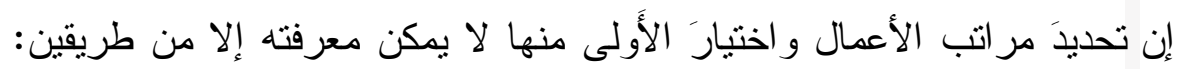

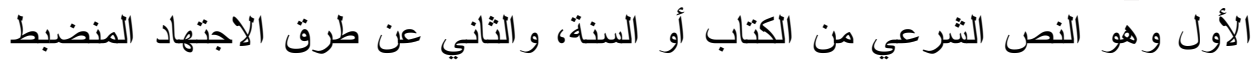
وفق مسالك الاجتهاد وضو ابطه الثر عية.

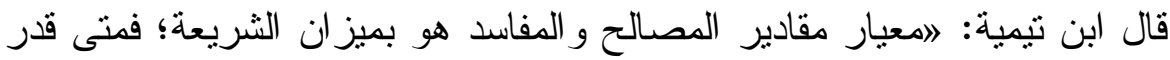

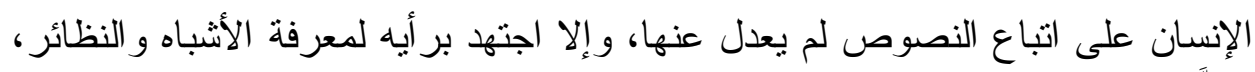

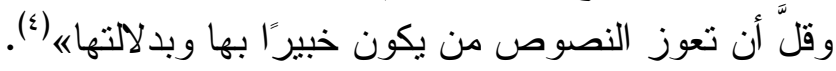

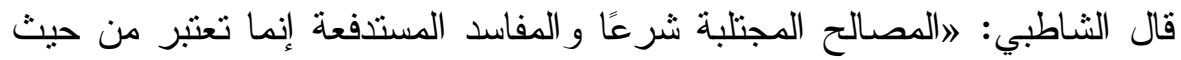
تقام الحياة الدنيا للحياة الأخرى، لا من حيث أهو اء النفوس في جلب مصالحها العال العادية،

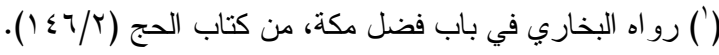

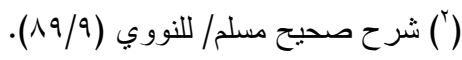

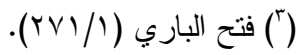

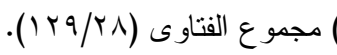


أو درء مفاسدها العادية، و الدليل على ذلك أمور : أحدها: أن الشريعة إنما جاءت لتخرج

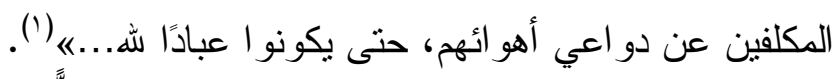

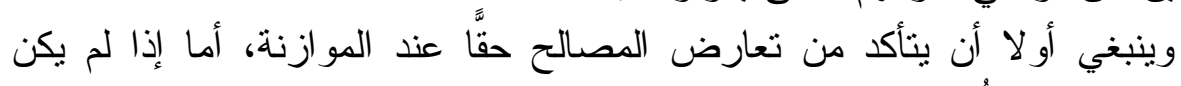

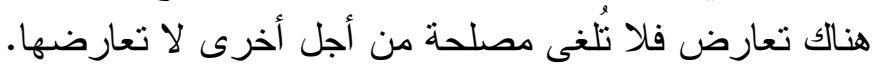

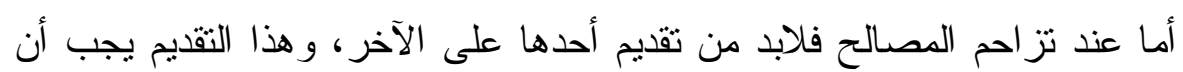

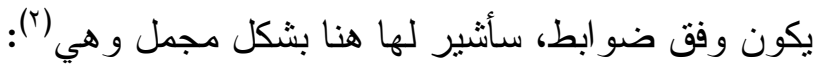
الضابط الأول: الأكثر مصلحة أولى بالتقديم من الأقل مصلحة. الضابط الثاني: الأكثر مفسدة أولى بالدرء من الألى الأقل مفسدة.

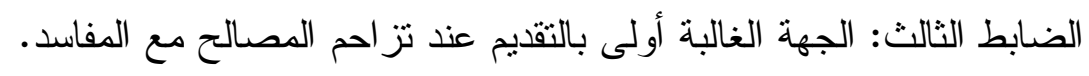
الضابط الر ابع: جهة المفسدة أولى بالدر ء عند تساوي المصالح مع الفيم المفاسد.

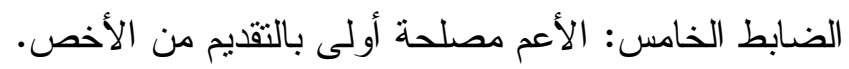

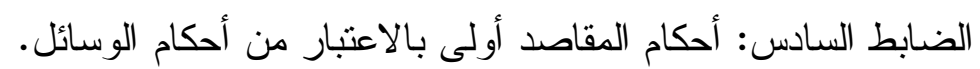

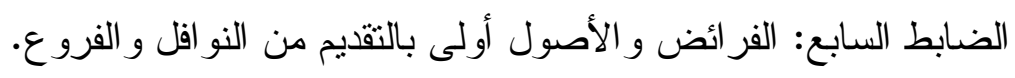

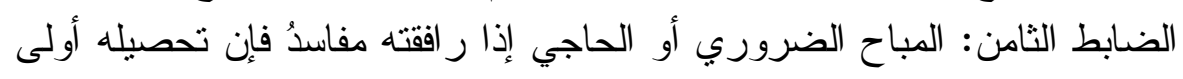
من تركه.

الضابط التاسع: الفوري أولى بالتقديم من المتر اخي.

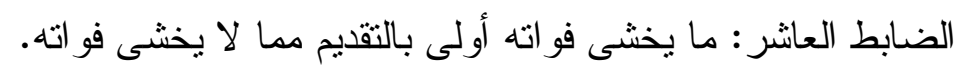
الضابط الحادي عشر: الواجب المضيق أولى بالتقديم من المطلق. الضابط الثاني عشر : القربات الاجتماعية أولى من القربات الفئ الفردية.

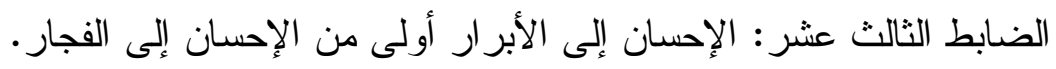

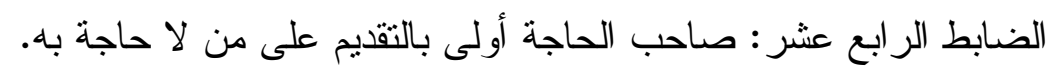

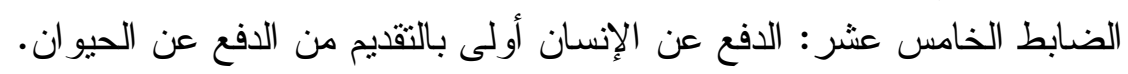
الضابط الساد عشر : قضاء الو اجب أولى من الاشتنغال بالنو افل.

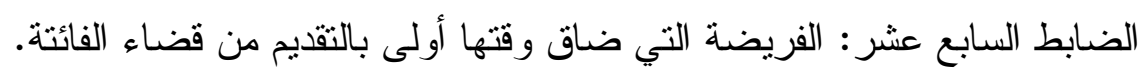
الضابط الثامن عشر: الأخص أولى بالتقديم من الأعم.

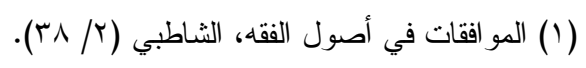

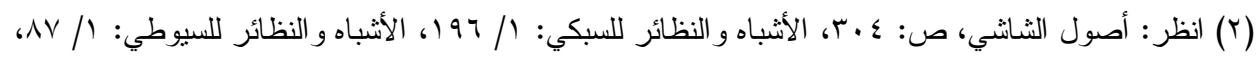

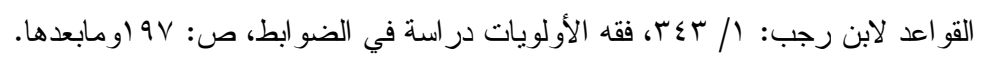


الفصل الثاني

تطبيقات فقهية لمسائل تتعلق بفقه الأولويات

وفيه خمسة مباحث:

المبحث الأول: الفرائض أولى بالتقديم من النوافل والمستحبات:

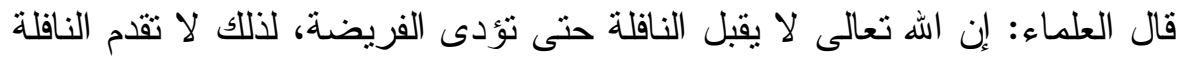

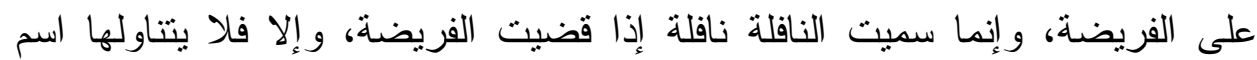

(النافلة (') (الفي

كما جاء عن أبي هريرة، قال: قال رسول الله

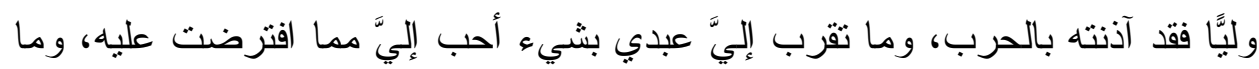

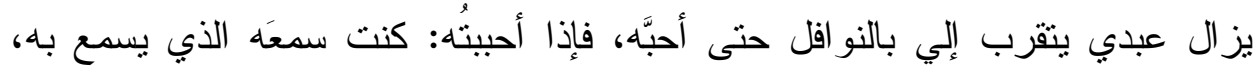

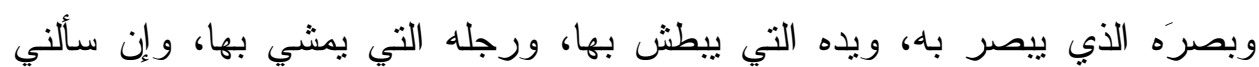

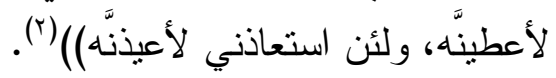

قال الحافظ رحمه الله: ويستفاد منه أن أداء الفرائض أحب الأعمال إلى الله، قال

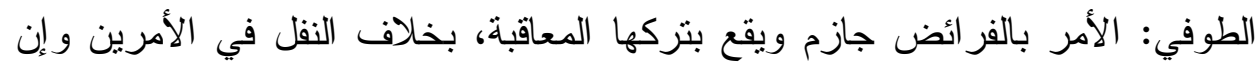

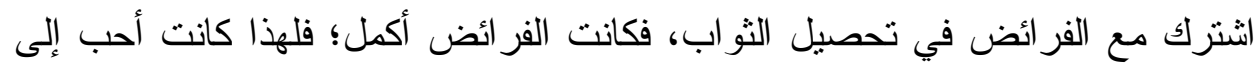

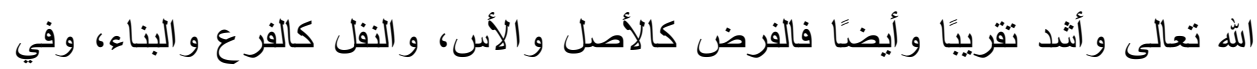

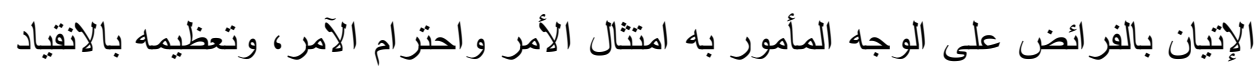

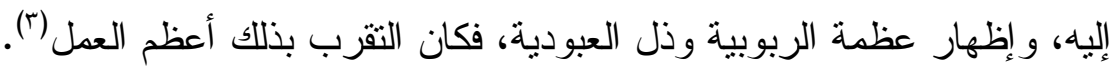

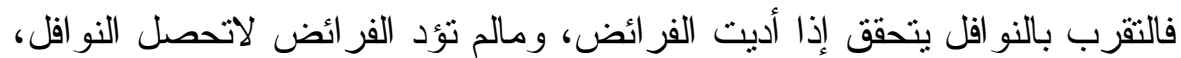

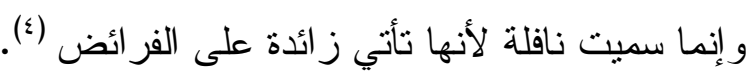

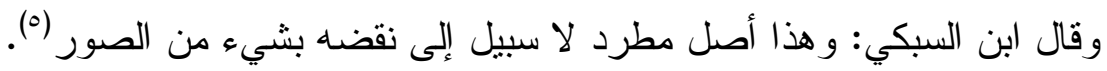

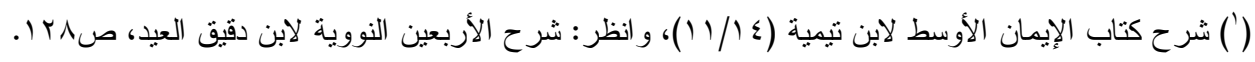

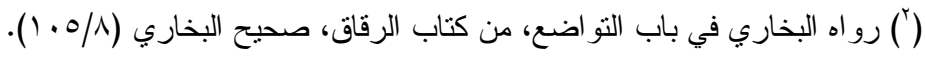

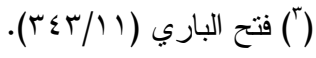

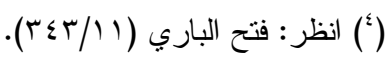

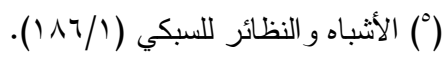




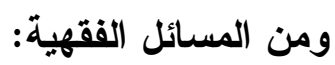

المسألة الأولى: إذا اجتمعت صلاة فريضة وسنة الطو اف تحيةً للمسجد الحرام

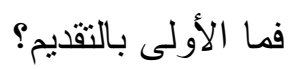

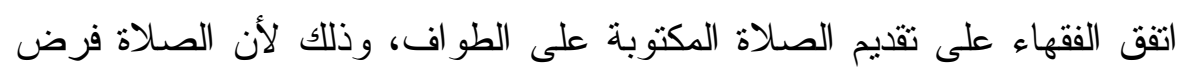

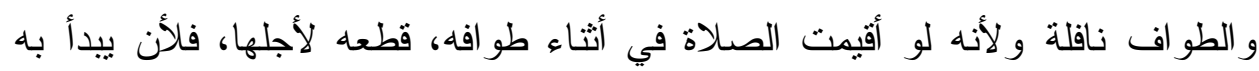

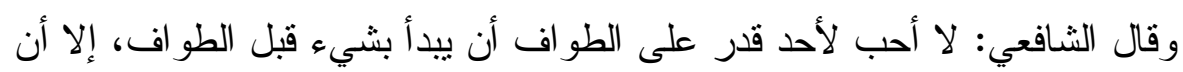

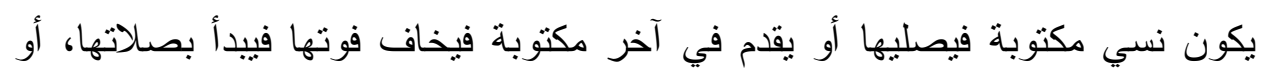

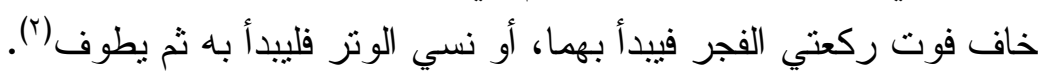

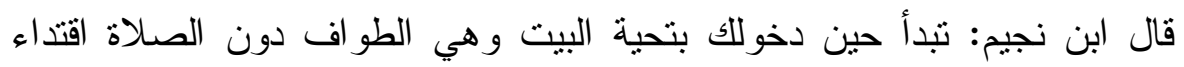

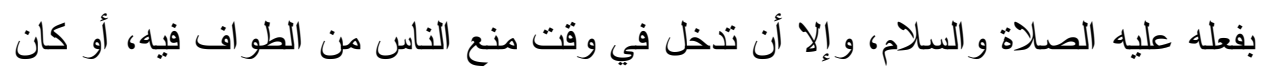
عليه فائتة، أو خاف خروج وقت المكتوبة، أو فوت جماعتها، أو الوتر أو سنة راتبة التها، فيقدم كل ذلك على الطو اف (־). المسألة الثاتية: إذا تعارض الفرض وضل هو الطهارة مع المستحب وهو الصلاة في

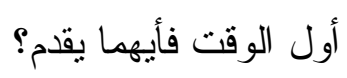
اتفق أئعة المذاهب الأربعة(๕) على أن الأفضل نأخير التيمم لآخر الوقت إن رجا وجود الماء حينئذ.

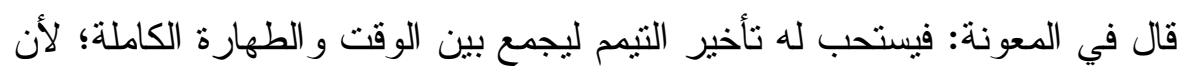

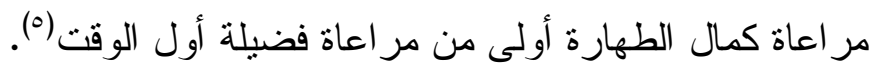

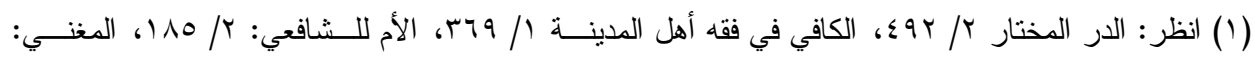

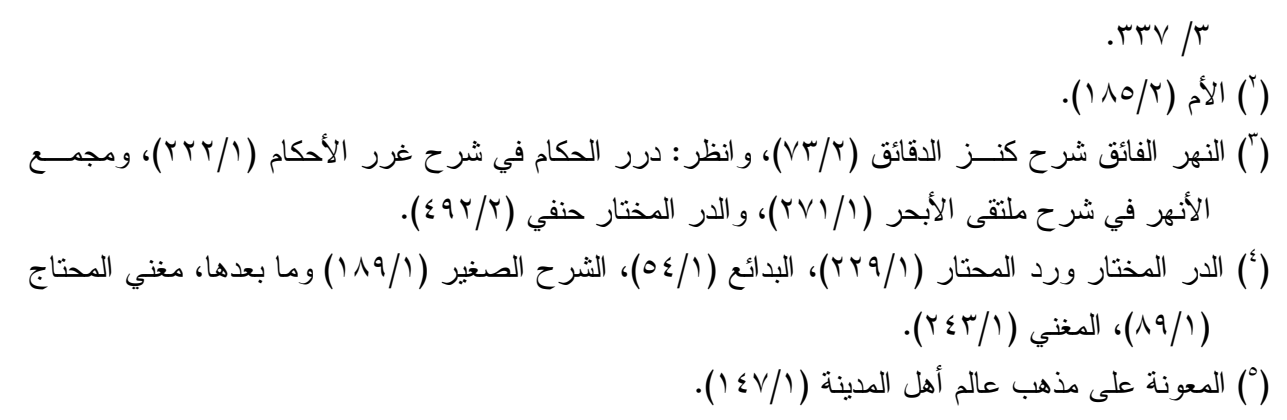


قال في الكافي: الأولى تأخير التيمم إلى آخر الوقت إن رجا وجود الماء، لقول

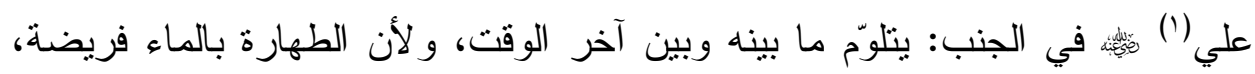

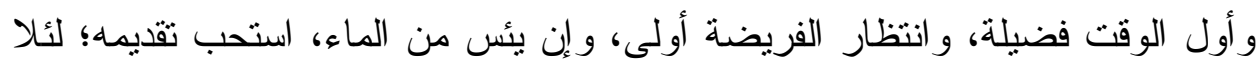
يترك فضيلة متيقنة لأمر غير مرجوّ"(r). قال ابن قامة: "(والاختيار تأخير النيم) ظاهر كلام الخرقي أن نأخير النيمم

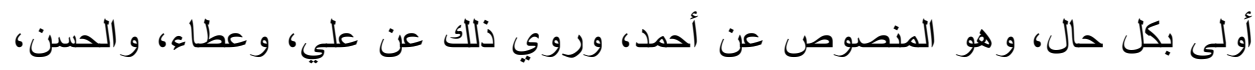

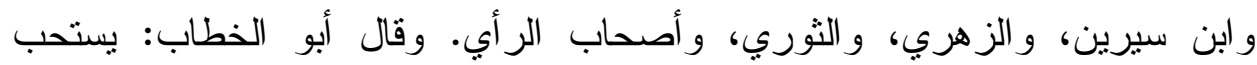

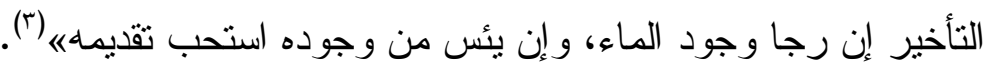

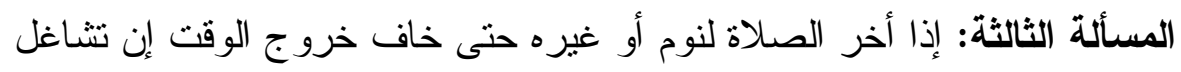

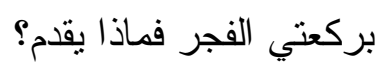

اتفق الفقهاء على أن الفرض أولى بالتقديم من النفل (i).

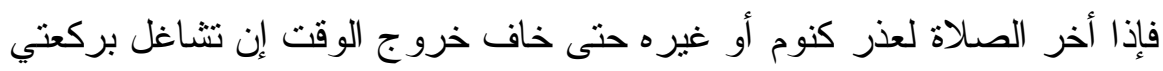

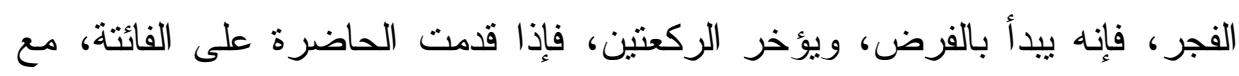

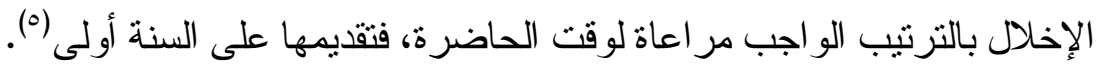

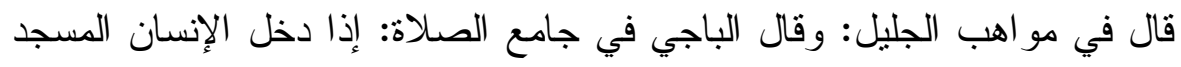

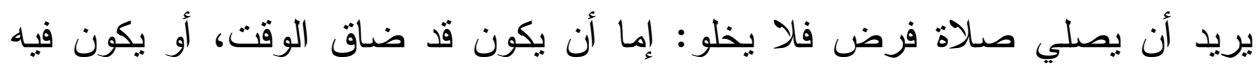

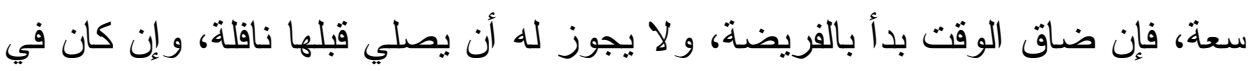

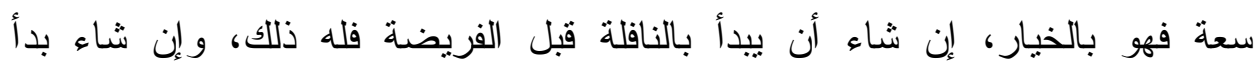
بالفريضة، وهو الأظهر من فعل ابن عمر انتهى (ج).

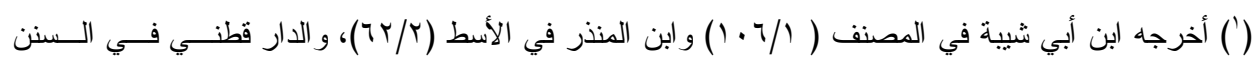

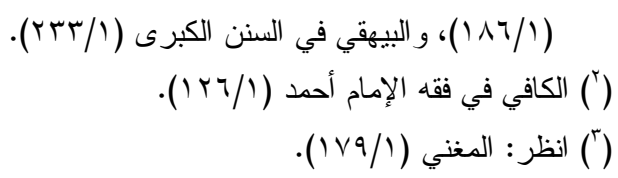

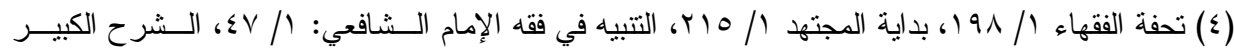
. $20 \leqslant / 1$

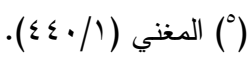

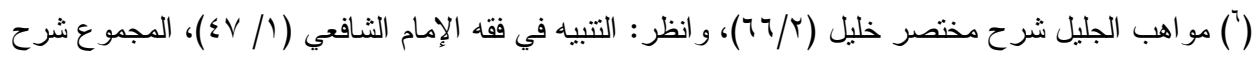

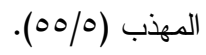


المبحث الثاني: الاهتمام بترك المنهيات أولى من الاهتمام بفعل المأمورات:

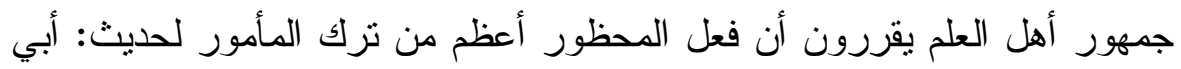

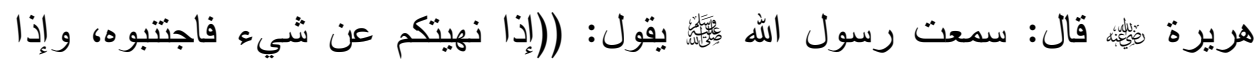

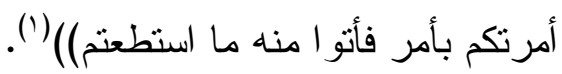

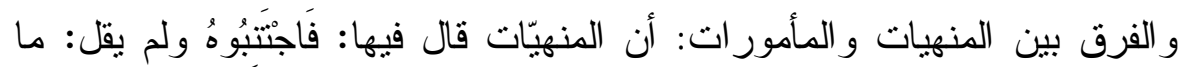

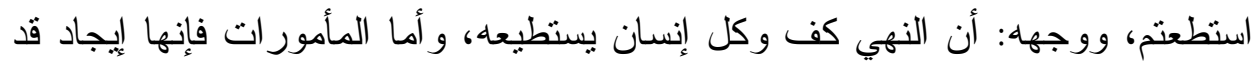

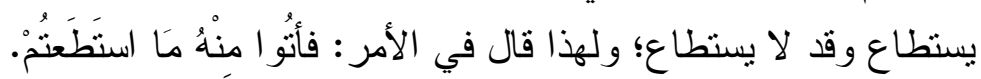
ومن التطبيقات:

المسألة الأولى: إذا ماتت المرأة مع الرجال ليس فيهم امرأة ولا زوج، أو مات

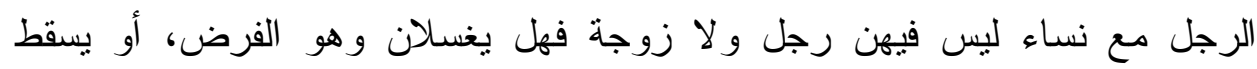

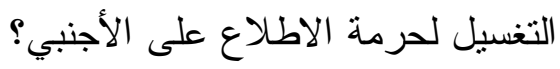
اختلف العلماء في هذه المسألة على أقوال، وسبب اختلافهم: هو التزجيح بين تغليب النهي على الأمر، أو الأمر على النهي، وذلك أن الغسل مأمور به، ونظر الرجل الرجل إلى بدن المر أة و المر أة إلى بدن الاعن الرجل منهي عنه.

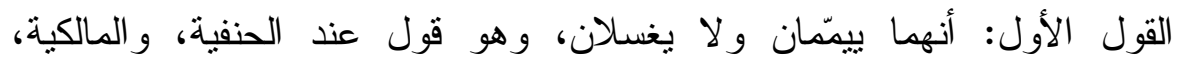

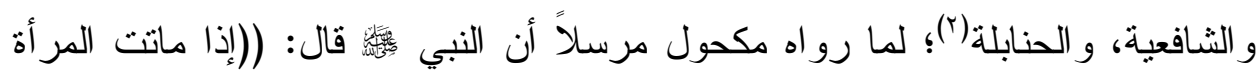

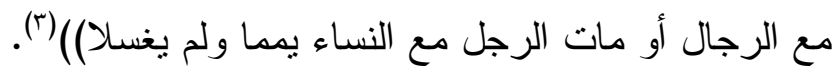

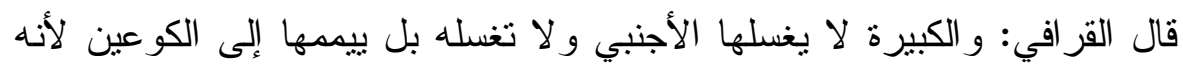

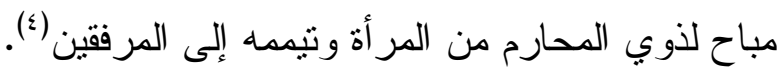

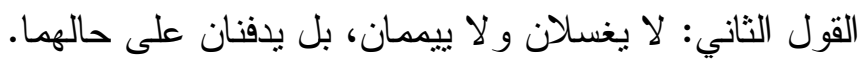

(') رواه البخاري، في باب الاقتداء بسنن رسول اله

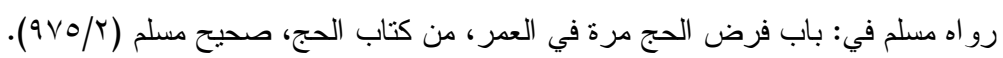

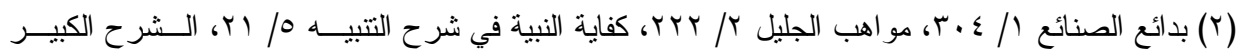
$. \Sigma \wedge / 7$

(") رو اه البيهقي في السنن الكبرى في باب المر أة تموت مع الرجال ليس معهم امــر أة مــن كتــاب الجنــائز

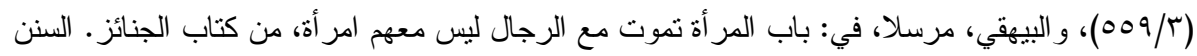

$$
\begin{aligned}
& \text { الكبرى (r/ ^ه r). }
\end{aligned}
$$

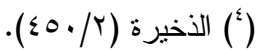


قال ابن الر افعة: وفي البيان قال الأوزاعي: لا ييمم و لا يغسل بل يدفن ('). القول الثالث: يغسلان من خلف القميص بلا تجريد. ذكر اللخمي في التبصرة: أن مالكًا أجاز في المدونة أن يغسل كل ولن واحد منهما الآخر من فوق الثوب(؟). قال في كفاية النبيه في شرح التنبيه: وفي المسألة وجه آخر أنه يغسل مع حائل من ثوب، ويلف الغاسل على يده خرقة...، و الأولى إذا غسل أن يكون في موضع وفيه مظلم، وهذا الوجه رجحه الإمام وحكاه عن القفال، ولم يورد القاضي الحسين فيما إذا لوال

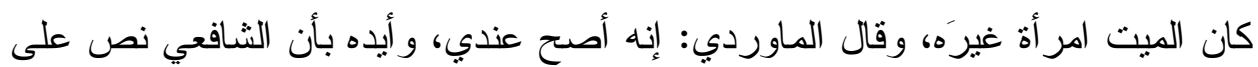

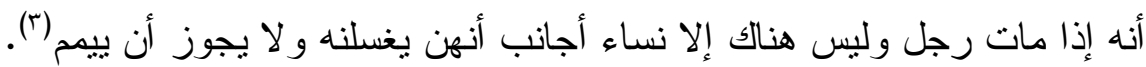

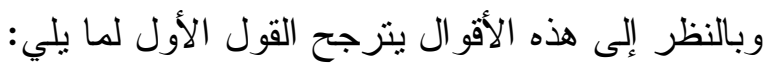

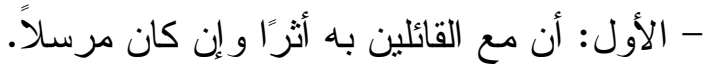
- الثاني: أنه وسط بين القولين. - الثالث: لأن الغسل من غير مس لا يحصل به التتظيف، و لا إز الة النجاسة، بل ربما

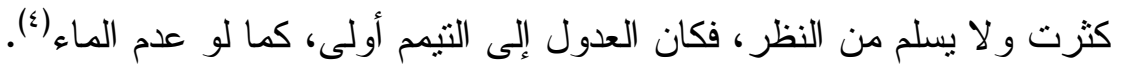

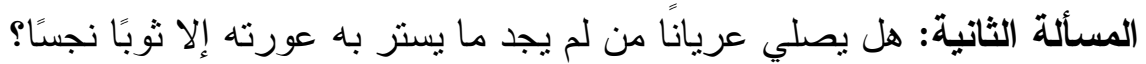
اختلف العلماء في هذه المسألة على أقو ال:

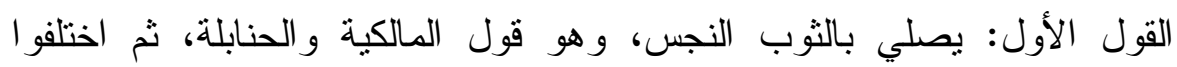

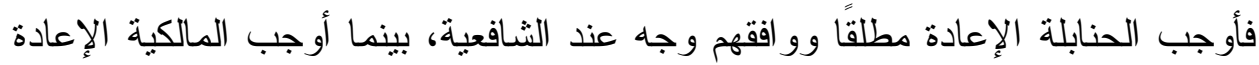
في الوقت إذا قدر على الصلاة بثوب طاهر في الوقت، فإن لم يقدر لم تجب الإعادة.

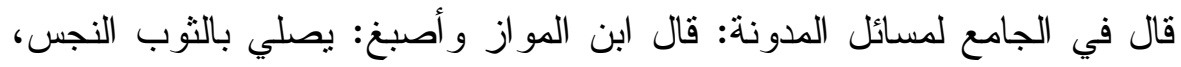
ويعيد في الوقت إن وجد غيره(ْ).

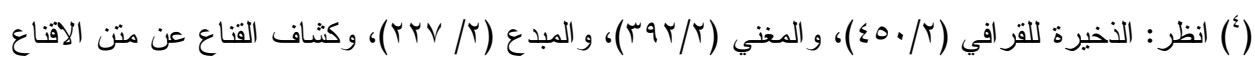


وقال ابن قدامة: قال أحمد: يصلي فيه، ورلا يصلي عريانا، وهو قول مالك،

و المزني (')

القول الثاني: يصلي عريانا، و لا يعيد؛ لأنها سترة نجسة، فلم تجز لله الصلاة فيها، كما لو قدر على غيرها. وهو قول الثافعية.

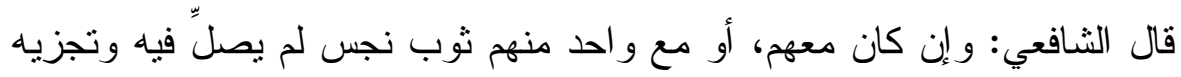

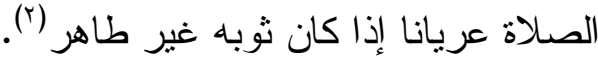
القول الثالث: إن كان جميعه نجسًا فهو بالخيار في الفعلين؛ لأنه لا بد من فير ترك و اجب في كلا الفعلين، وفعل و اجب، فاستويا وهو مذهب الحنفية.

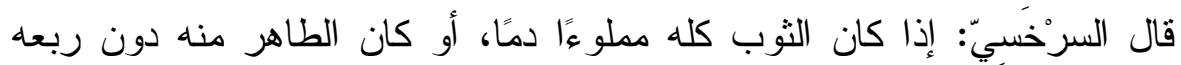
فعند أبي حنيفة وأبي يوسف يخير بين أن يصلي عريانا وبين أن يصلي فيه وهو

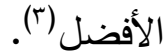

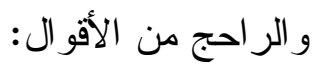
القول الأول: وهو جواز الصلاة في التوب النجس إذا لم يجد غيره ولا يصلي

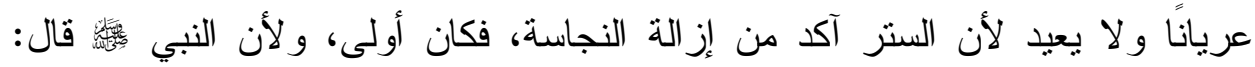

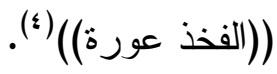

قال شيخ الإسلام ابن تيمية: اوقد تنازع العلماء في التيمح لخثية البرد: هل يعيد؟

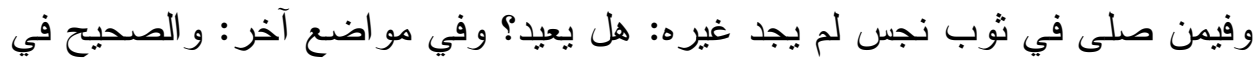

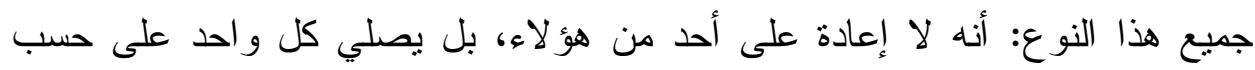

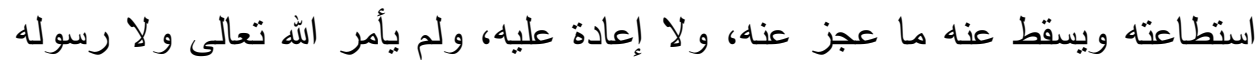
أحدًا أن يصلي الفرض مرنين مطلقاه (०).

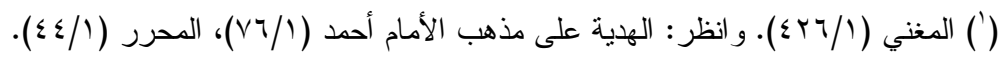

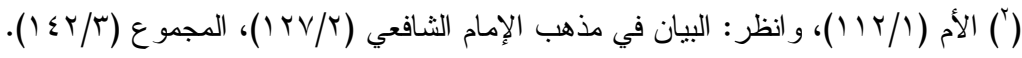

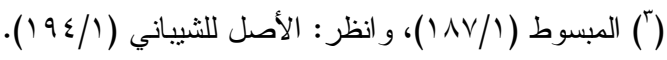

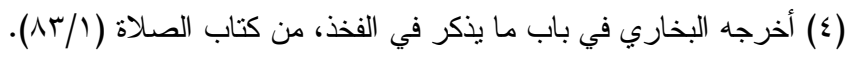

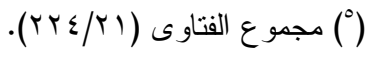


المبحث الثالث: الأكثر مصلحة أولى بالتقديم من الأقل مصلحة:

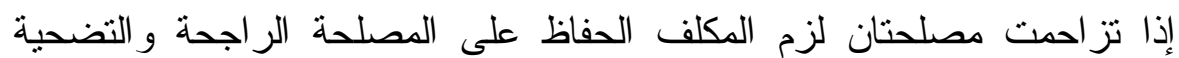
بالمصلحة المرجوحة، فيما إذا عجز عن الجمع بينهما وصيانتهما معًا. وليس معنى هذا أن المصلحة المرجوحة التي أهدرت لم تعد مصلحة، ولكن

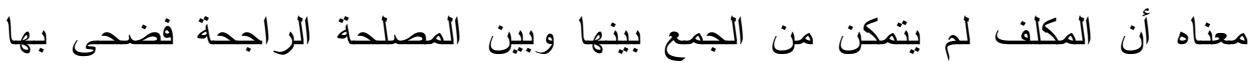

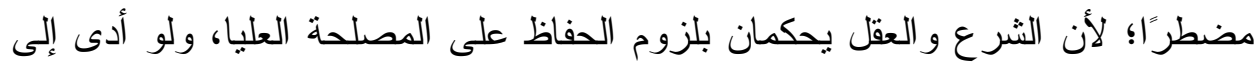
تفويت الدنيا. و المصلحة المفوتة في هذه الحال لم تعد مطلوبة؛ لذا فإن تركها لأجل تحصيل

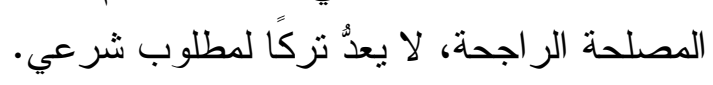
قال ابن القيم: لاوقاعدة الثرع و القدر تحصيل أعلى المصلحنين و إن فات

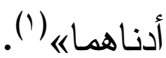
تطبيقات (ققهية) لأولوية المصلحة الكبرى على المصلحة الصغرى:

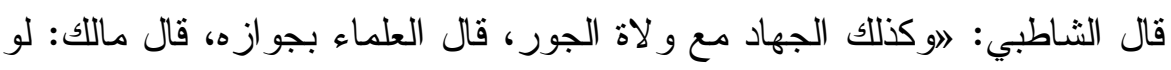

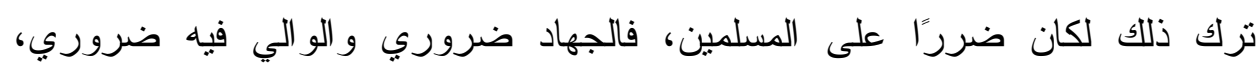

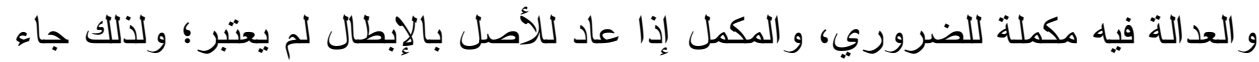

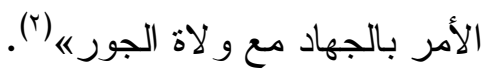

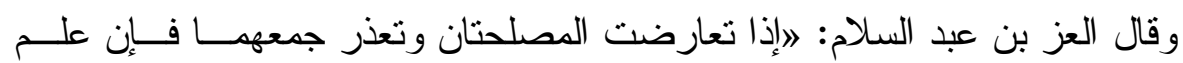

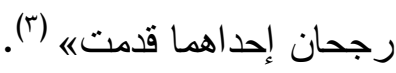
ومن الأمثلة التي ذكرها ابن القيم لهذا لها (النوع):

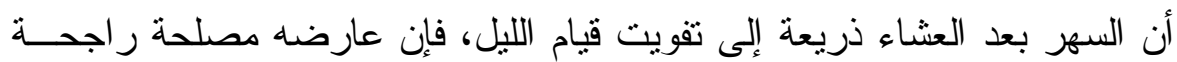
كالسهر في العلم ومصالح المسلمين لم يكره (ء).

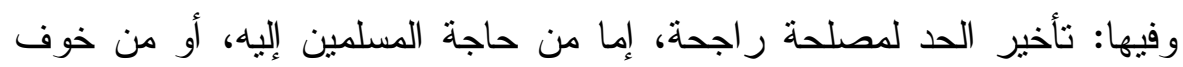

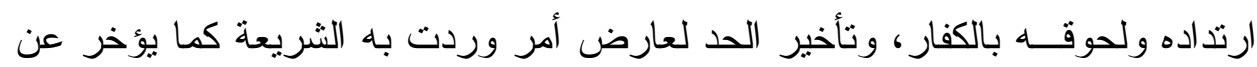

$$
\begin{aligned}
& \text { (') (') إعلام الموقعين (rV9/r). }
\end{aligned}
$$

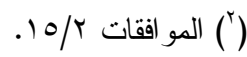

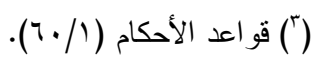

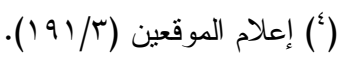


الحامل و المرضع، و عن وقت الحر و البرد و المرض، فهذا لمصلحة المحدود، فتأخيره

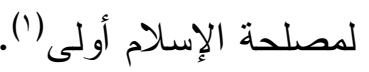

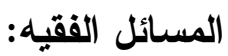
من الأولى بحضانة البنت بعد سبع سنين. اختلف العلماء في الجارية إذا بلغت السابعة من الأولى بحضانتها على ثلانثة

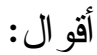

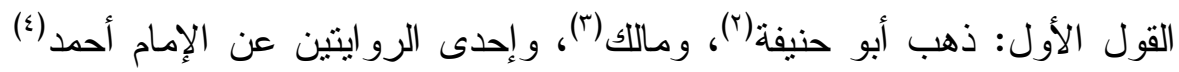

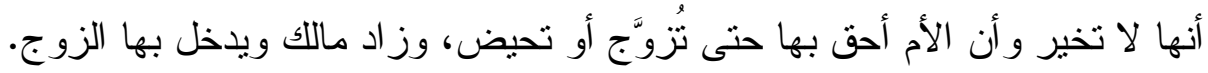

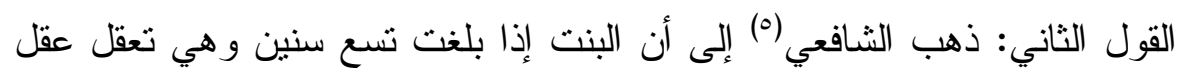
مثلها خيرت كالصبي بين أمها و أبيها، وكانت مع من اختارت منهات البها.

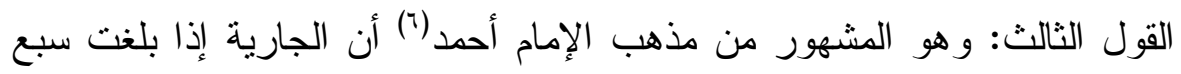
سنين فالأب أحق بها.

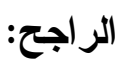

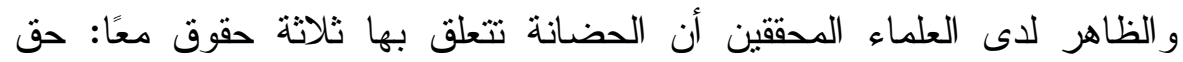
الحاضنة، وحق المحضون، وحق الأب أو من يقوم مقامه، فإن أمكن التوفيق بين هذه

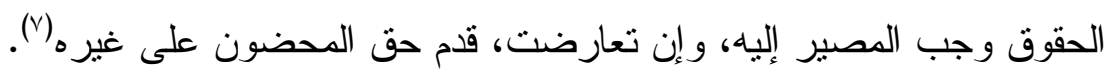

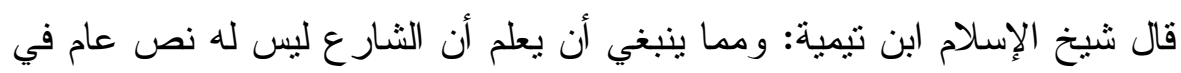

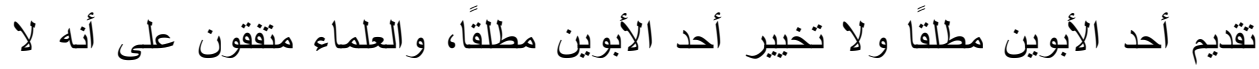

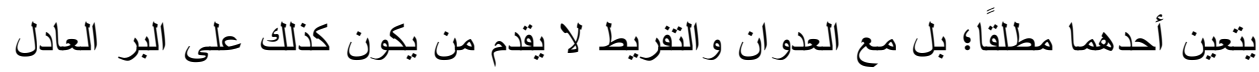

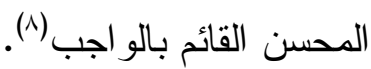

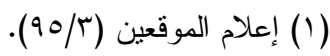

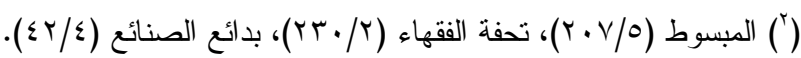

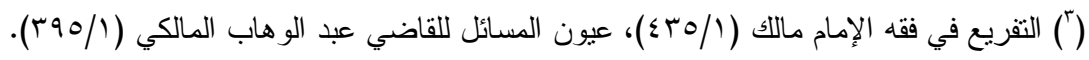

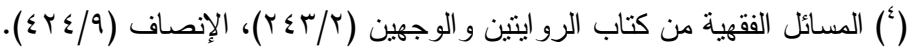

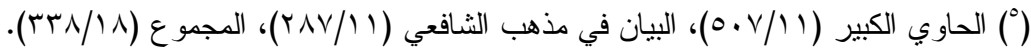

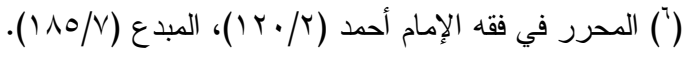

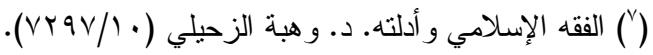

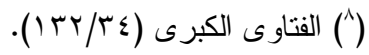


وقال أيضا: وأما (الصبي المميز) فيخير تخيير شهوة حيثما كان، كلُ من الأبوين

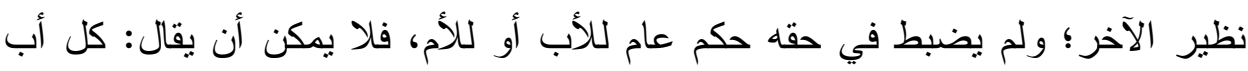

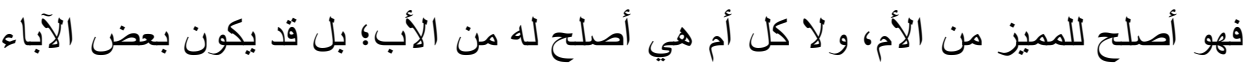

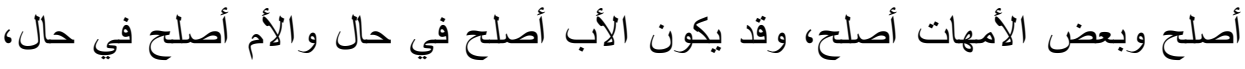

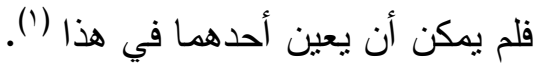

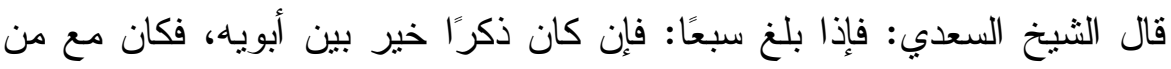

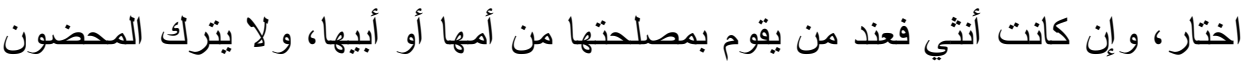

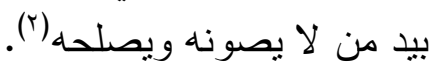

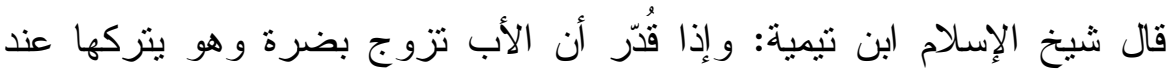

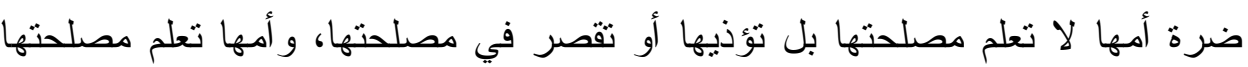

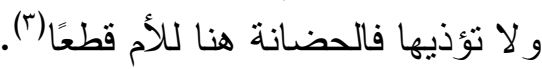
المبحث الرابع: تقديم العمل المتعدي نفعه إلى الغير على العمل القاصر نفعه على

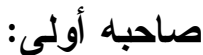
فمن فقه الأولويات في ترجيح العمل: أن يكون أكثر نفعًا من غيره، وعلى قدر نفعه للآخرين يكون فضله وأجره عند الله.

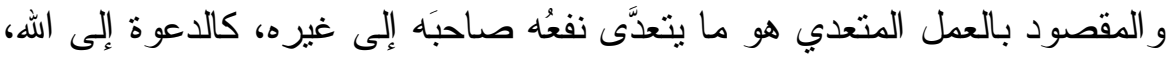

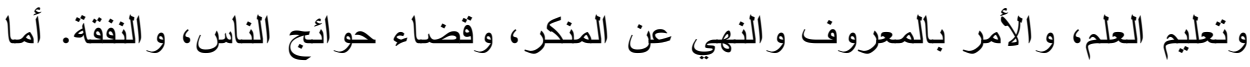

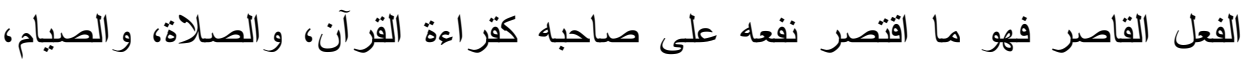

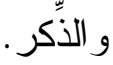

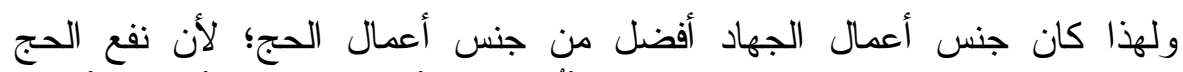

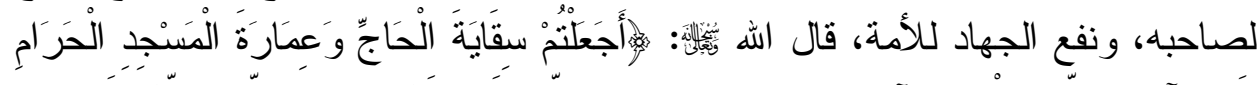

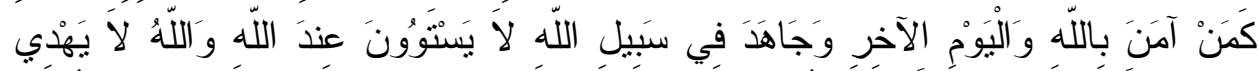

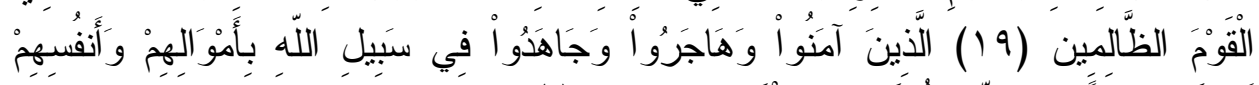

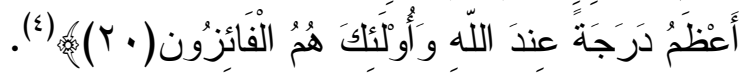

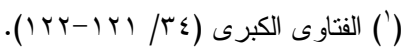

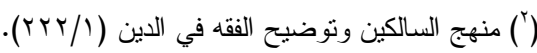

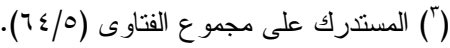

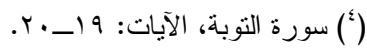


وقد أرشد الرسول

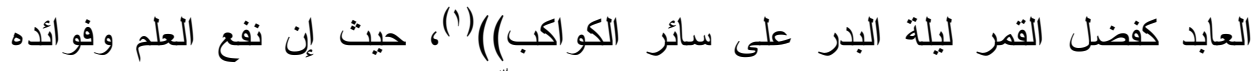

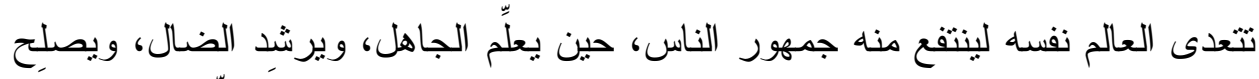

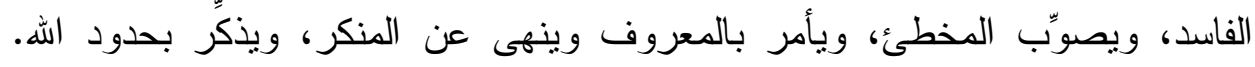

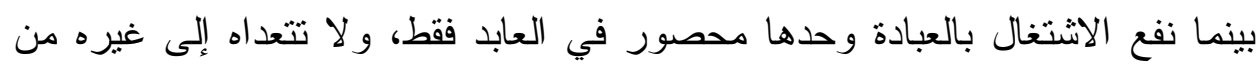
جمهور الناس؛ ولهذا كان الانشغال بالعلم مقدمًا على الانشغال بنو افل العبادة.

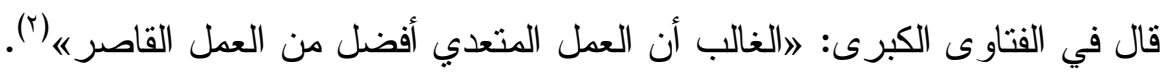

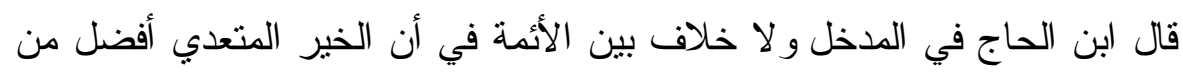
الخير القاصر على المرء نفسه(؟). وقال الثافعي: 》طلب العلم أفضل من صلاة النافلةه) (؟).

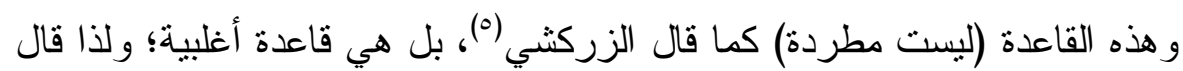

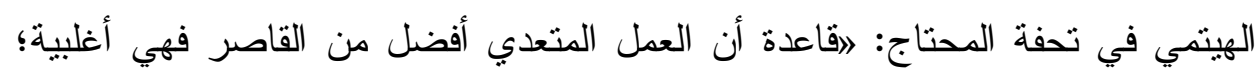

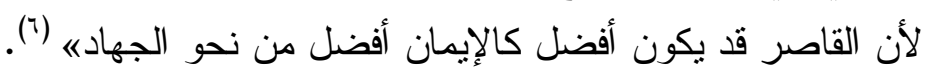
فتقديم العمل المتعدي على العمل القاصر وتقضيله عليه، مقيد بأن تكون الأعمال

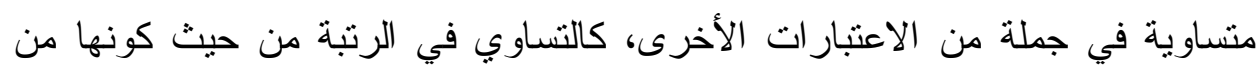

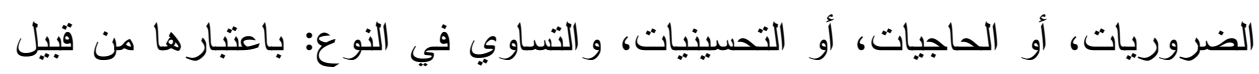

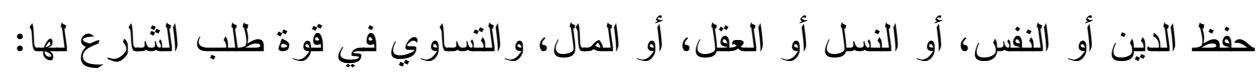

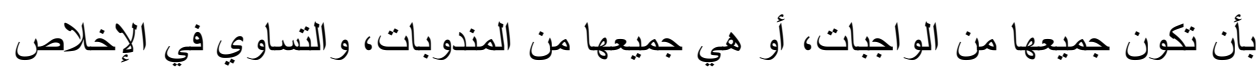

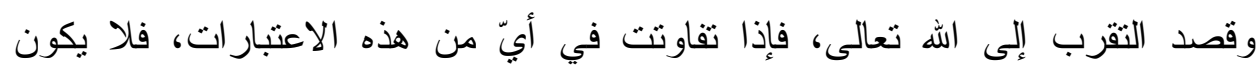

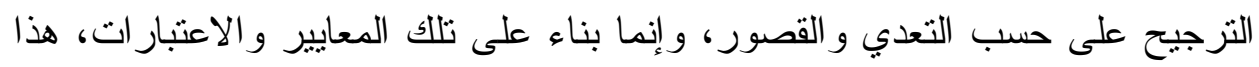

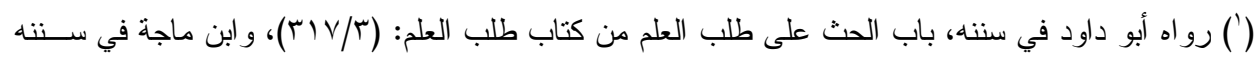

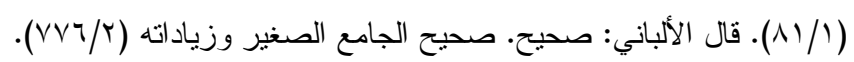

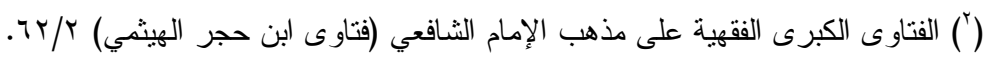
.(^9/1)( ()

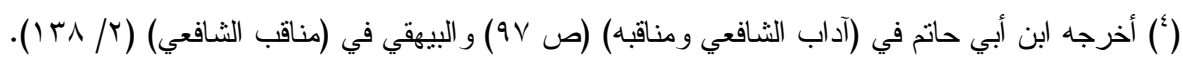

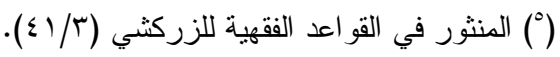

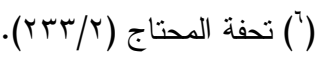


ما حدا بالعز بن عبد السلام إلى القول: "اربَّ عمل قاصر أفضل من عمل متعدًّ،

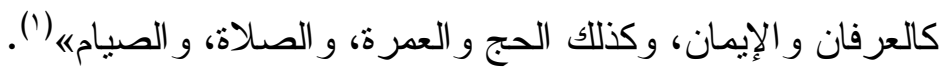
بل ذهب القرافي إلى أبعد من ذلك عندما نفى القاعدة من أصلها بقوله: 》اقول

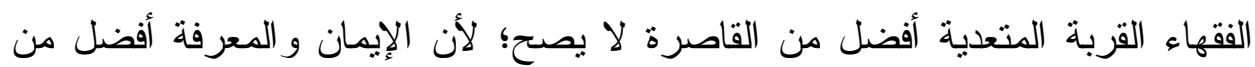

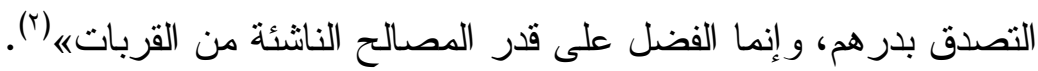

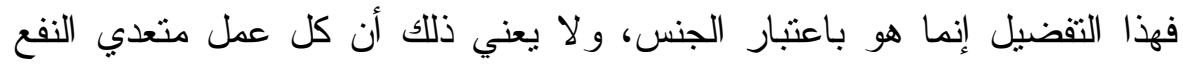

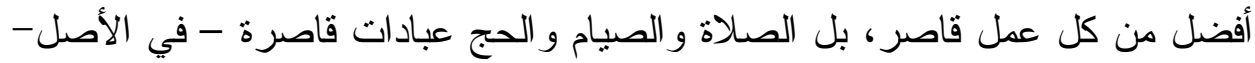

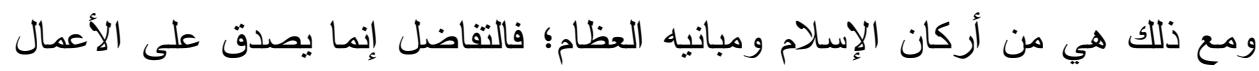

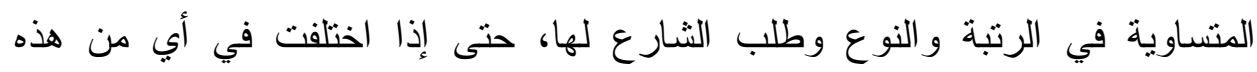

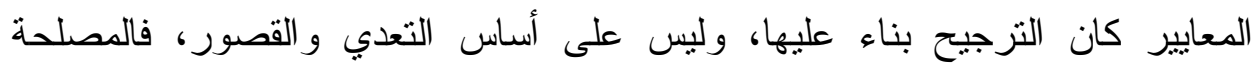
الضرورية القاصرة مقدمة على التحسينية المتعدية، ومصلحة الواجب القاهي القاصرة مقدمة على مصلحة المندوب المتعدية. ومن التطبيقات الفقهية:

تفرق الصحابة والتابعون في الأمصار، وتركوا مكة والمدينة مع المضاعفة

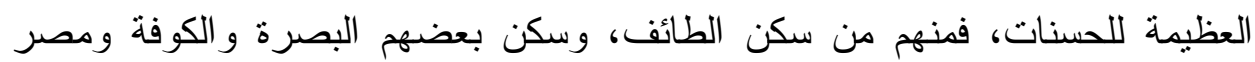
و الثام، وهكذا من جاء بعدهم تفرقو ا في الأمصار، وكان الباعث لهم هو نشر الدين،

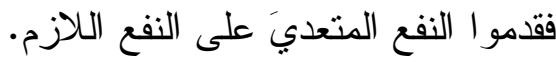
المسألكة الأولى: تقديم طلب العلم على نو الفل العبادات: اتفق الفقهاء على فضل العلم و أهله، وفضل العالم على العابد، وأن الاثتنغال بطلبه

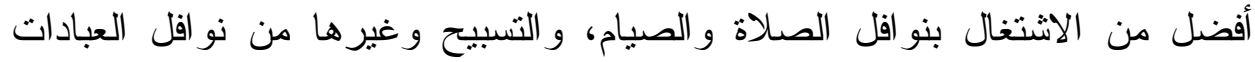

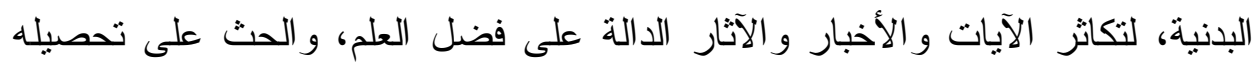
و الاجتهاد في اقتباسه ().

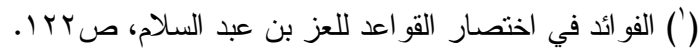

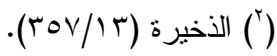

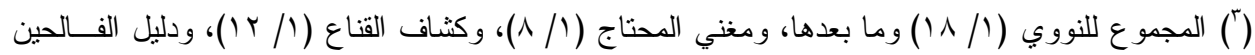
(lVY/६) 
فكلّما ازداد المسلم علما ازداد هدى وبصبرة وخثية لله تعالى كما قال سبحانه:

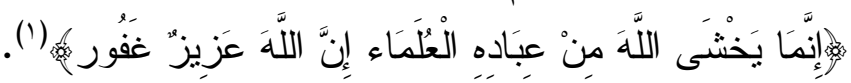

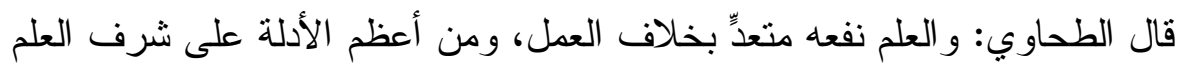

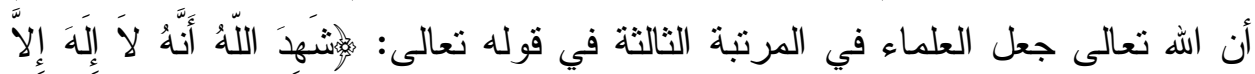

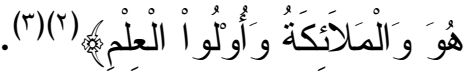
قال ابن الحاج: و لا بوجد في الأعمال كلها على ما تقدم في أول الكتاب أفضل من العلم (₹) وقال أحمد في رواية المروذي؛ وقد سئل عن رجل يقرئ في المسجد، ويريد أن يعتكف؟ فقال: إذا فعل هذا كان لنفسه، وإذا قعد كان له ولغيره، يقرئ أعجب إليَّيَ(ه).

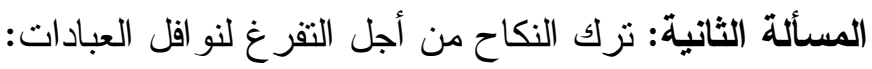
اختلف العلماء في هذه المسألة على قولين: القول الأول: لجمهور العلماء من الحنفية والمالكية والحنابلة، قالوا: إن النكاح

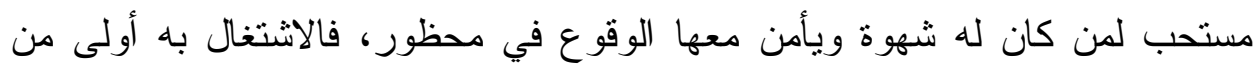
التخلي لنو افل العبادات؛ لكون مصالحه عامة، ونو افل العبادة خاصة. قال ابن قدامة: الاشتغال له به أولى من التخلي لنو افل العبادة، وهو قوله ونول أصحاب

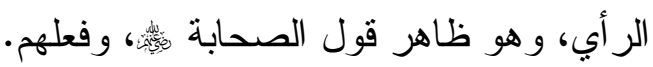
وقال ابن دقيق العيد في شرح حديث الثناثة الذين جاؤوا إلى بيوت النبي وظاهر الحديث ما ذكرناه من ثقديم النكاح، كما يقوله أبو حنيفة ولا شك أن الن الترجيح

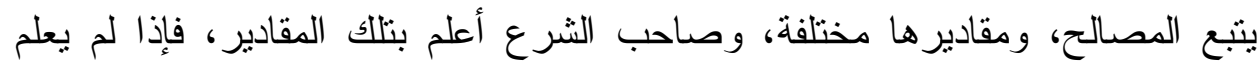
المكلف حقيقة تلك المصالح، ولم يستحضر أعدادها، فالأولى اتباع اللفظ الوارد في

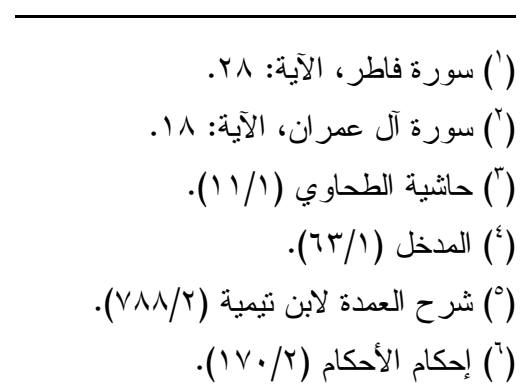


وقال في اللباب: اباب الاشتغال بالنكاح أفضل من التخلي لنو افل العباداته؛ لأن

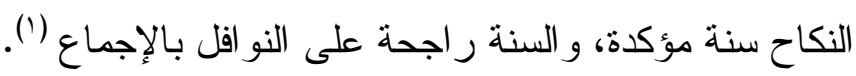

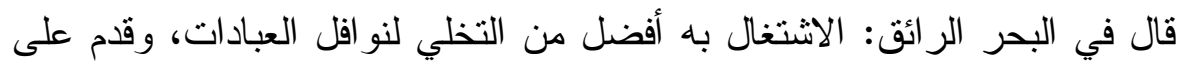

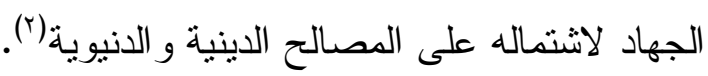

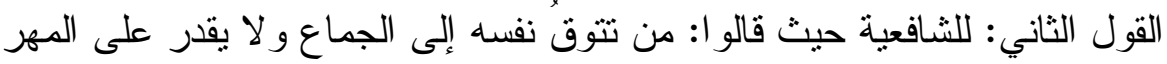

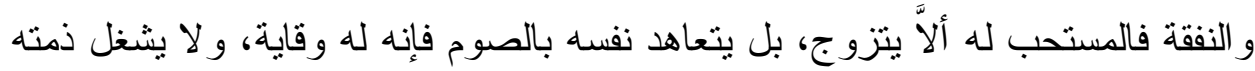

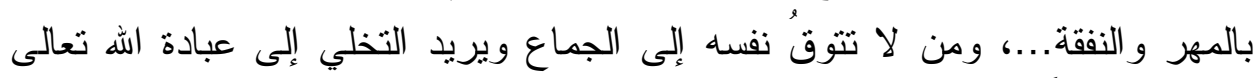

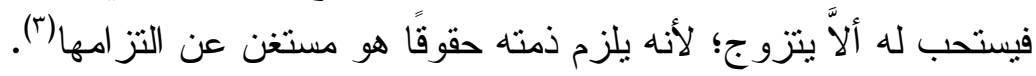

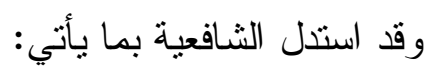

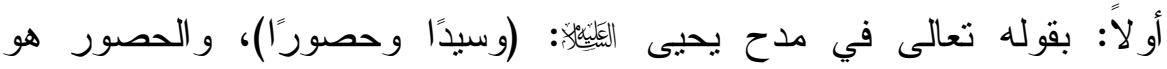

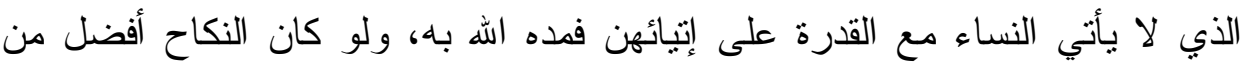

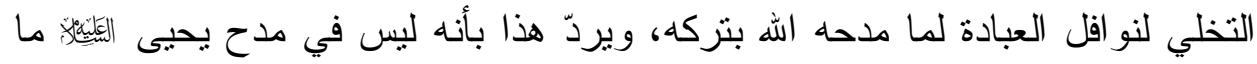

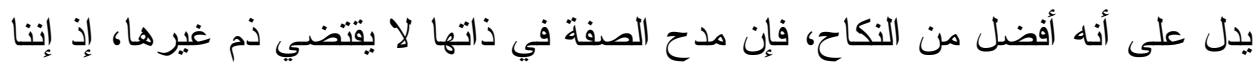
لا ننكر فضل التخلي للعبادة، واستحقاق المدح عليه، ولكن نقول: إن الاشتغال بالنكاح

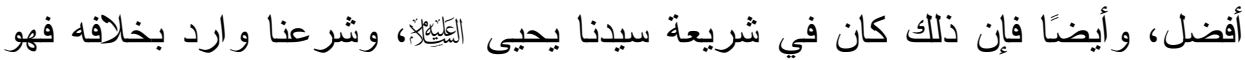
أولى.

وثانيًا: قالوا النكاح عقد معاوضة فكان الاشتغال بالعبادة أفضل منه كالبيع،

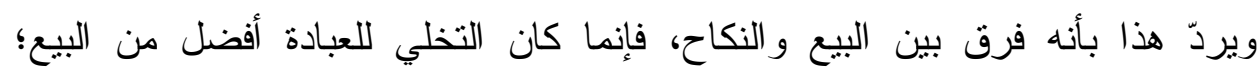

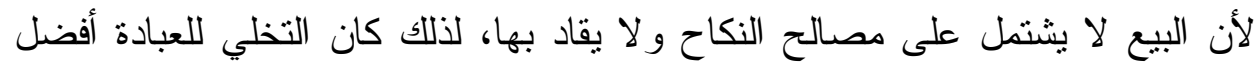
منه (๕)

و واستدل الجمهور : بما ورد من أمر الهه تعالى ورسوله به وحثنها عليه، قال

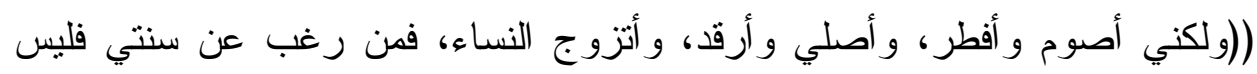

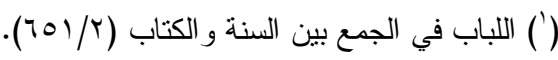

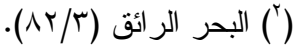

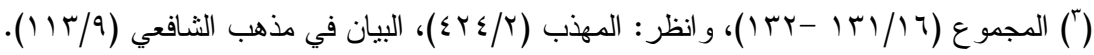

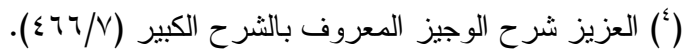


مني))(')، وقال سعد: لقد ((رد النبي "(1) على عثمان بن مظعون التبتل))، ولو أحله له لاختصينا متفق عليهما (ب).

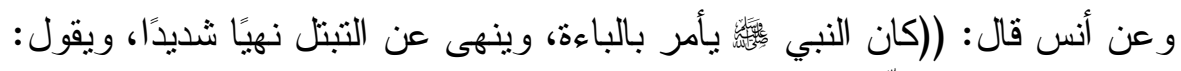

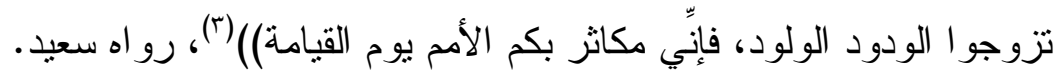

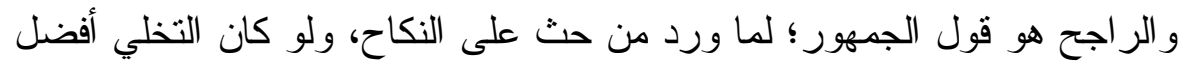

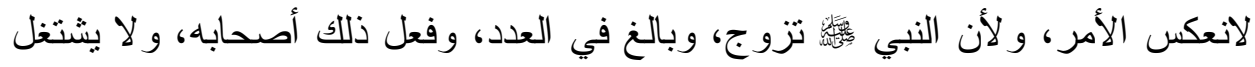
النبي بالأدنى، ومن العجب أن من يفضل التخلي لم يفعله! فكيف أجمعو ا على النكاح في

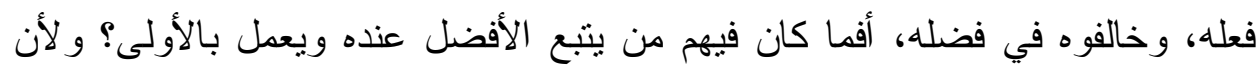

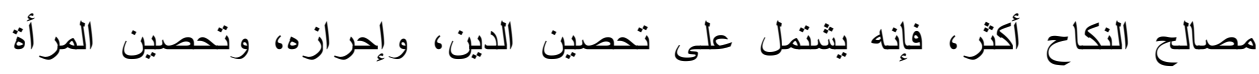

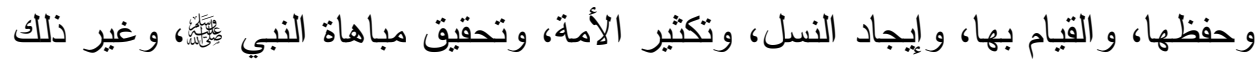

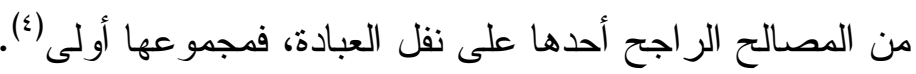
المبحث الخامس: التيسير أولى من التعسير:

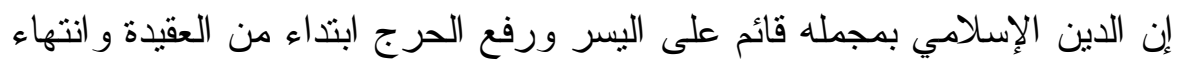

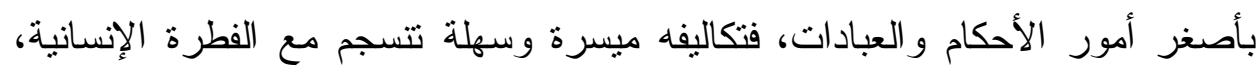

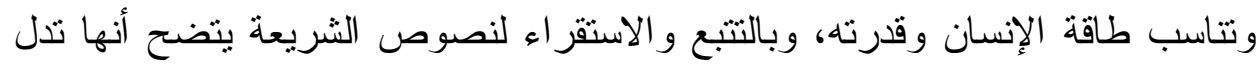

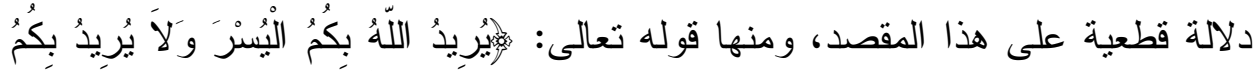

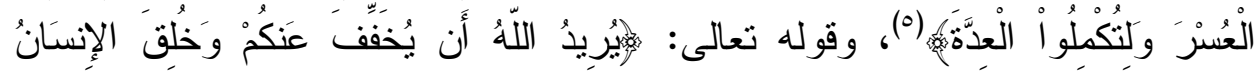

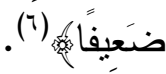

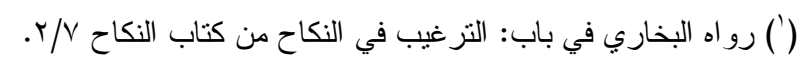

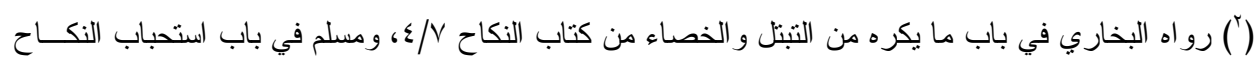

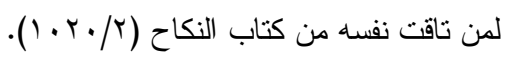

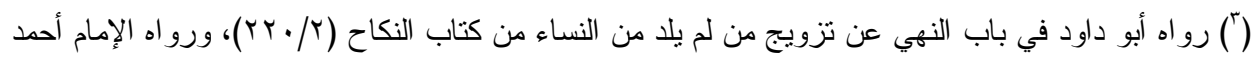

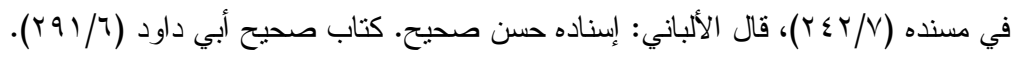
( ) أ) المغني (O/V)

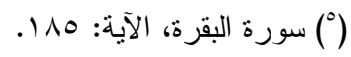

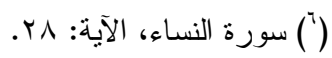


يقول أهل التفسير: إن الله

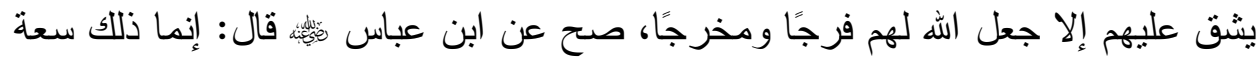

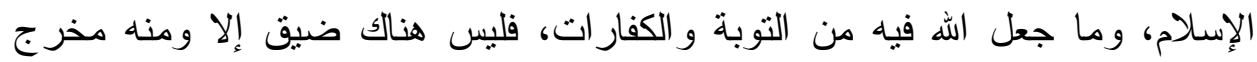

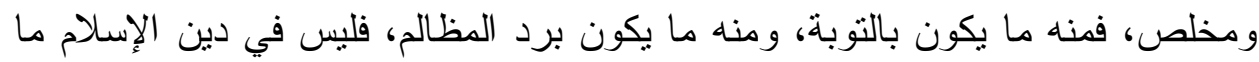
لا سبيل إلى الخلاص من عقوبته. قال ابن القيم في كتابه أعلام الموقعين ('): فإن الشريعة مبناها وأساسها على الحكم ومصالح العباد، في المعاش و المعاد، وهي عدل كلها، ورحمة كلها، ومصابه اعلح كلهان كلها،

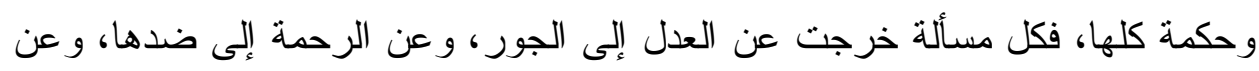

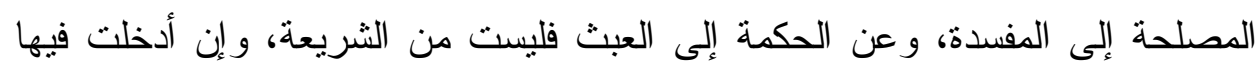

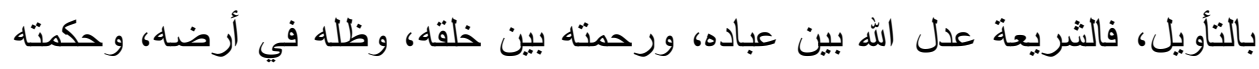

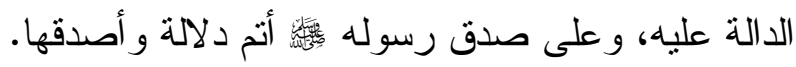
وقد ذكرت صفة الرسول

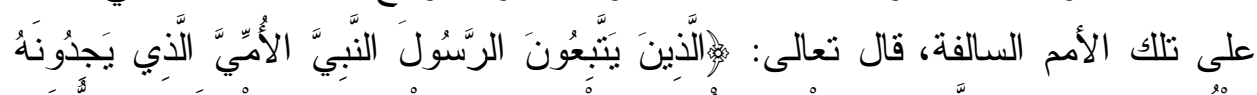

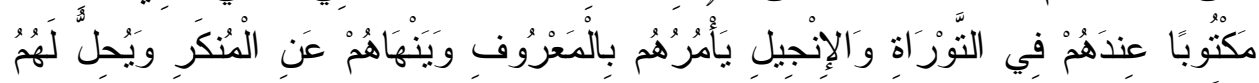

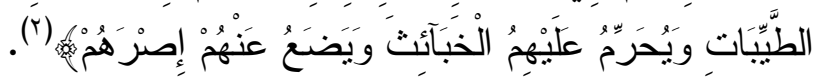

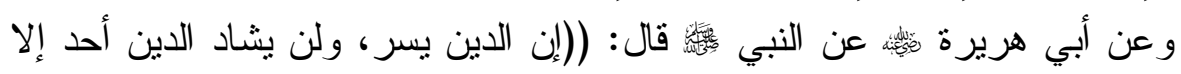
غلبه، فسددو ا وقاربو ا وأبشرو ا، و استعينو ا بالغدوة و الروحة وشيء لئه من الدالجة)).

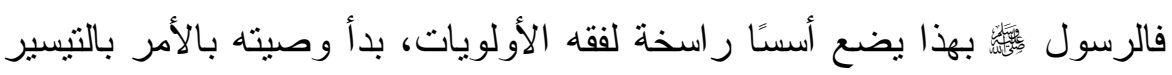

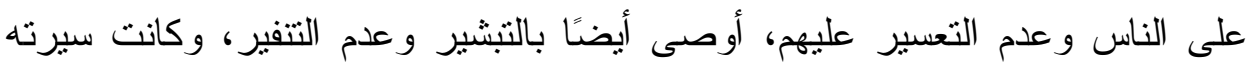

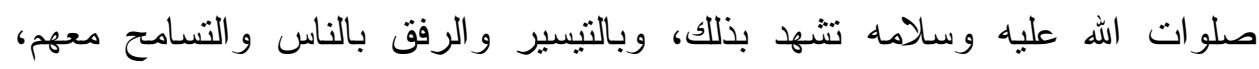

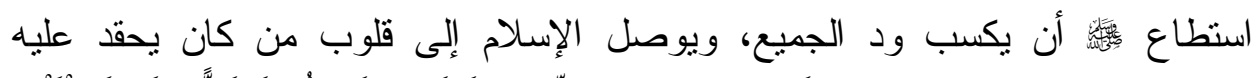

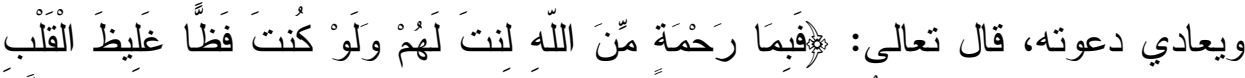

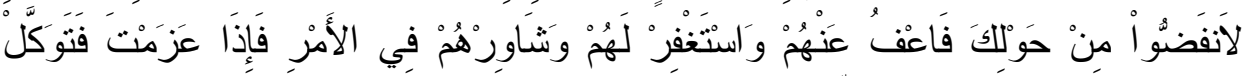

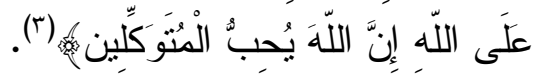

. (1 $1 \leqslant / r)(')$

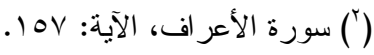

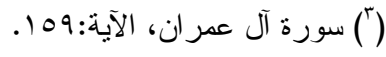




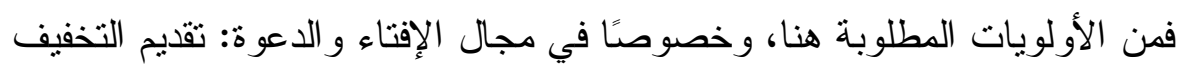

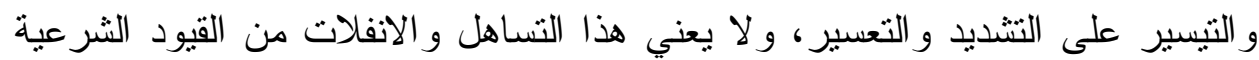
و التهاون فيها، و إنما يعني فقط الرفق وعدم التكليف بما لا بطاق.

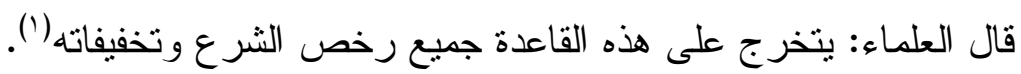
وقال السيوطي: هذه القاعدة يرجع إليها غالب أبو اب الفقه (؟). ومن التطبيقات الققهية:

مسألة: إذا كثر الثك في الصلاة حتى صدار وسو استًا:

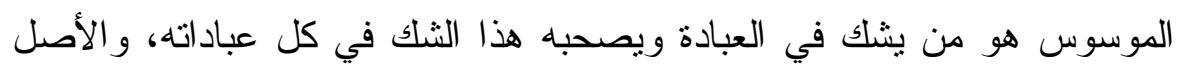

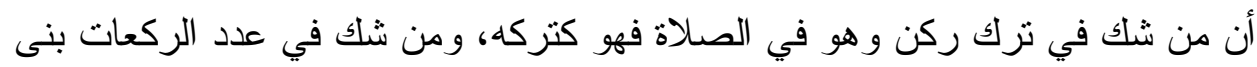

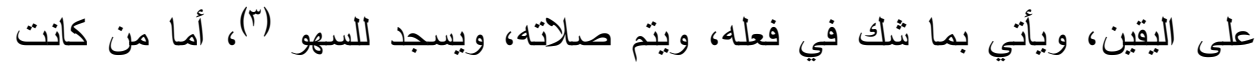

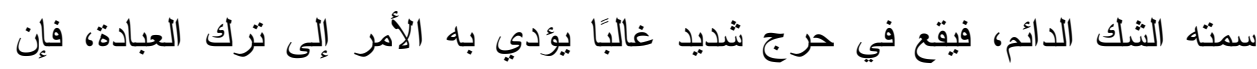

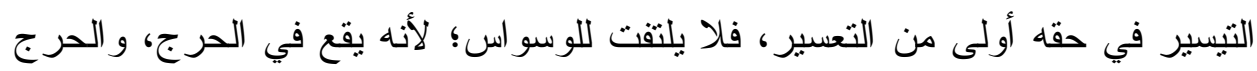
منفي في الشريعة، بل يمضي على ما غلب في نفسه؛ تخفيفًا عنه وقطعًا للوسو اس. يقول ابن قدامة: و إذا رفع رأسه، وشك هل ركع أو لا، أو هل أتى بقدر الإجز اء

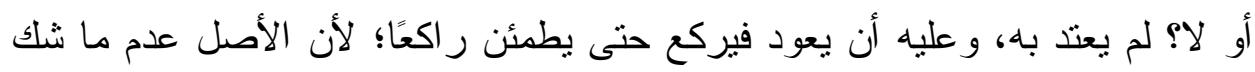

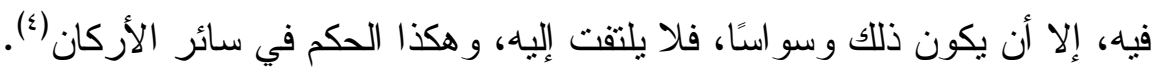

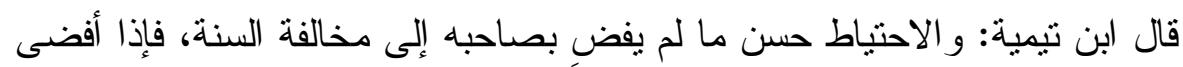
إلى ذلك فالاحتياط ترك هذا الاحتياط (ْ).

\footnotetext{
(') الأشباه و النظائر للسيوطي، ص VV و الأثباه و النظائر لابن نجيم، صع T.

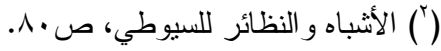

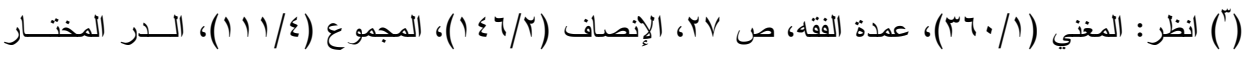
.$(r 90 / r)$

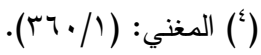

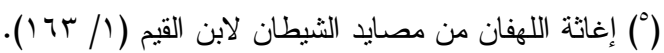


الحمد لله الذي بنعمته تتم الصالحات، و الصلاة و السلام على سبينا وحبيينا محمد

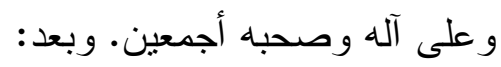

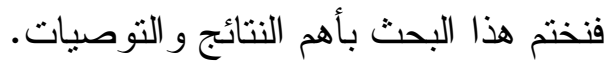

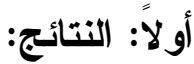
1- أن الأحكام و الأعمال و التكاليف متفاوتة في نظر الثرع تفاوتًا بليغًا، وليست كلها في رنبة واحدة، و الفهم الصحيح للشريعة يستلزم معرفة فقه الأولويات، وكيفية

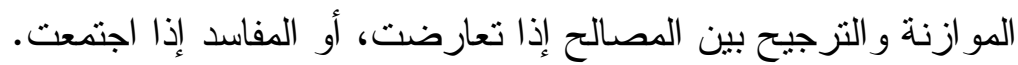
r- أن غياب فقه الأولويات من حياة الأمة يؤدي إلى مفاسد لا تحمد التهارئ عقباها.

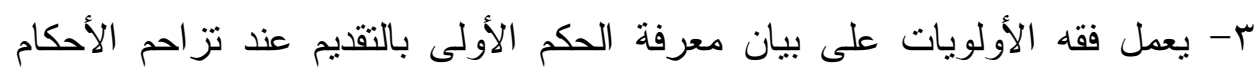
الثر عية أثناء التطبيق و العمل. ع - الفر ائض أولى بالتقديم من النو افل و المستحبات. ه- جمهور أهل العلم يقررون بأن فعل المحظور أعظم من نرك المأمور .

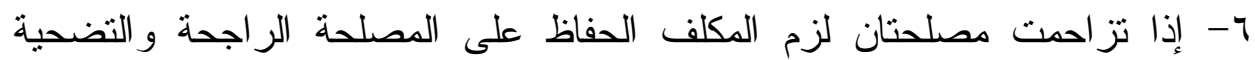
بالمصلحة المرجوحة، فيما إذا عجز عن الجمع بينهما وصيانتهما معًا.

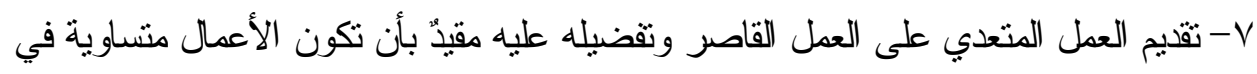

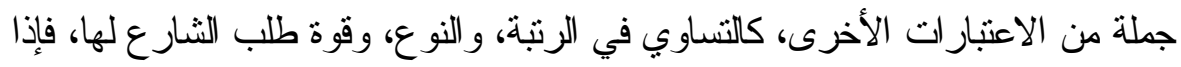

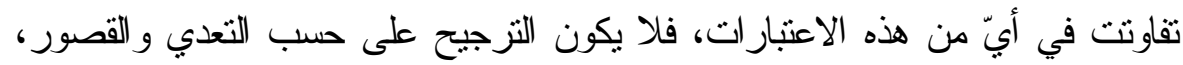

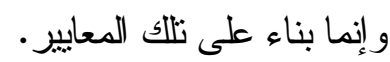
1- تقديم التخفيف والتيسير على التشديد والتعسير لا يعني التساهل و الانفلات من القيود الثرعية و التهاون فيها، و إنما يعني فقط الرفق، وعدم التكليف بما لا يطاق. ثانيًا: التوصيات: 1- توصي الباحثة طلبة العلم و الباحثن في جميع التخصصات القيام بالبحث و الكتابة في بيان

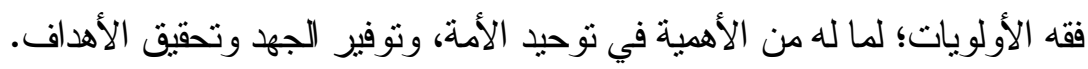

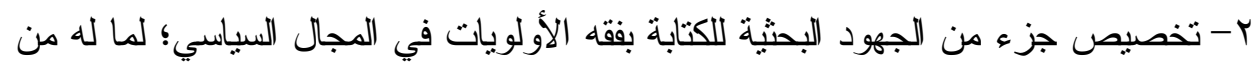

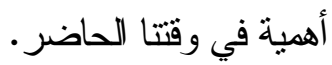

$$
\text { و الحمد لله رب العالمين }
$$

وصلى الهه وسلم وبارك على سيدنا محمدو على آله وصحبه وسلم تسليما كثثرًا 


\section{أهم المصادر والمر اجع:

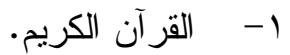

r- الأثباه و النظائر، السيوطي، عبد الرحمن بن أبي بكر، جلال الدين. طا، (د. م): دار الكتب العلمية، الإ؛ الهـ

r- الأشباه و النظائر على مذهب أبي حنيفة النعمان. ابن نجيم، زين الدين بن إبراهيم بن

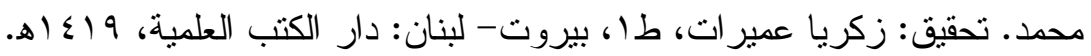

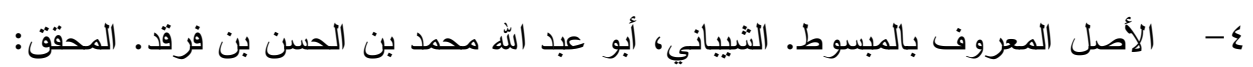
أبو الوفا الأفغاني (د. ط) كر انتي: إدارة القرآن و العلوم الإسلامية، (د. تـ).

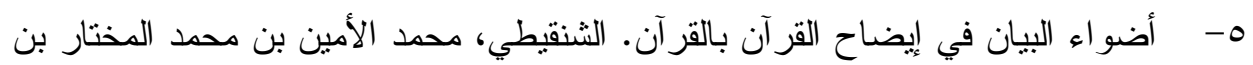

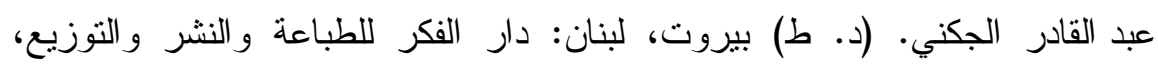
. $1990 / 81 \leqslant 10$

ج- إعلام الموقعين عن رب العالمين، ابن القيم، محمد بن أبي بكر بن أيوب بن سعد شمس

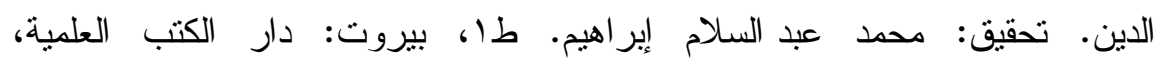

$$
\text { . } 1991 / 81 \leq 11
$$

- V الأم. الثافعي، أبو عبد الله محمد بن إدريس بن العباس بن عثمان بن شافع بن

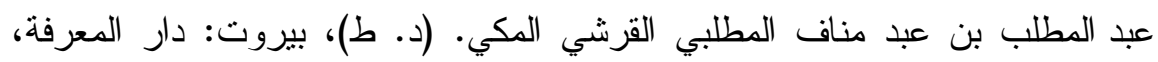

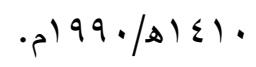

^- - الإنصاف في بيان أسباب الاختلاف (الثاه ولي الله الدهلوي)، أحمد بن عبد الرحيم بن

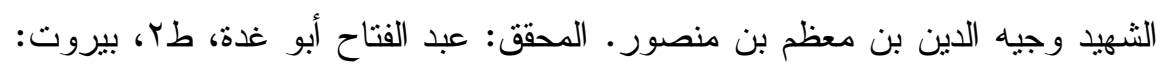

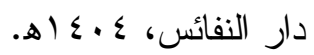

9- بدائع الصنائع في ترتيب الشرائع. الكاساني، علاء الدين، أبو بكر بن مسعود بن أحمد

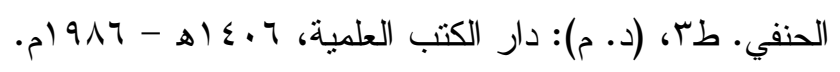

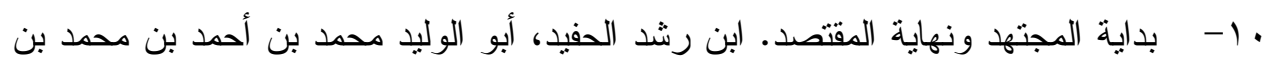

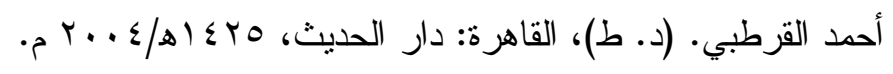

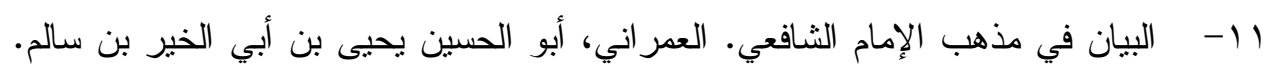

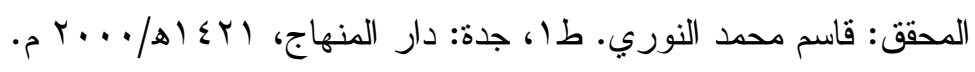


r ا- تحفة المحتاج في شرح المنهاج. ابن حجر ، أحمد بن محمد بن علي الهيتمي. (د. ط)،

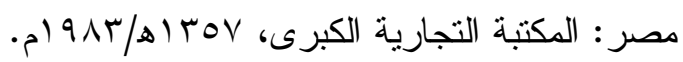

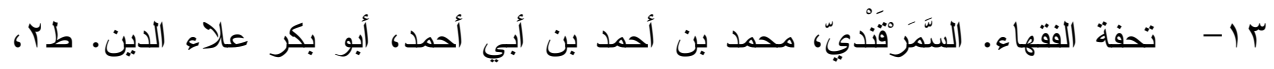

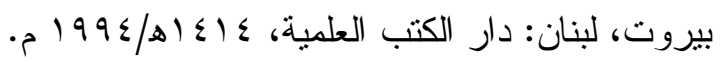

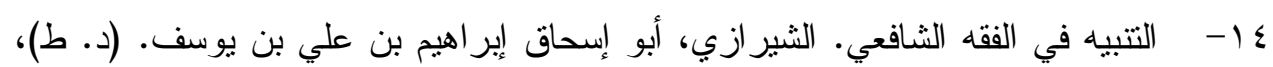

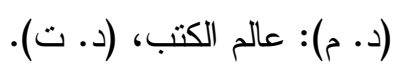

10- التفريع في فقه الإمام مالك بن أنس. ابن الجلاب، عبد الله بن الحسين بن الحسن أبو القاسم المالكي. المحقق: سيد كسروي حسن. طا، بيروت، لبنان،: دار الكتب العلمية،

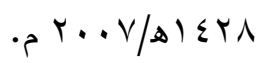

7 ا- تيسير الكريم الرحمن في تفسير كلام المنان. السعدي، عبد الرحمن بن ناصر بن

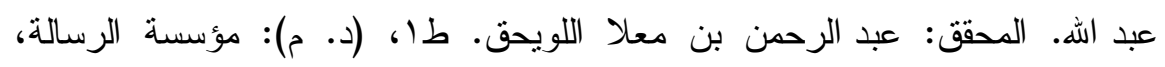

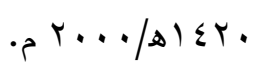

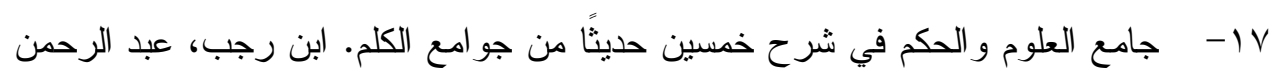

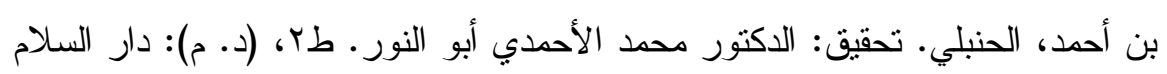

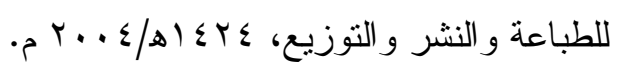

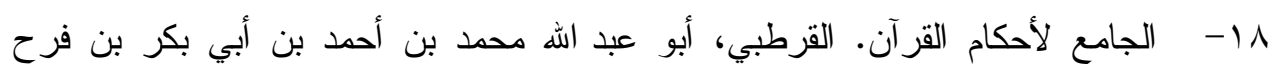

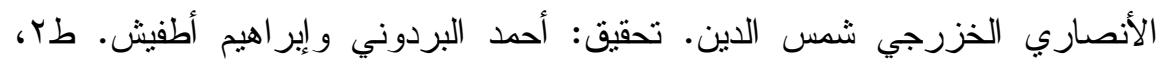

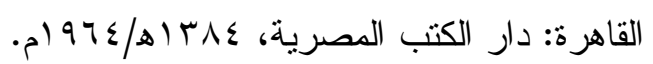

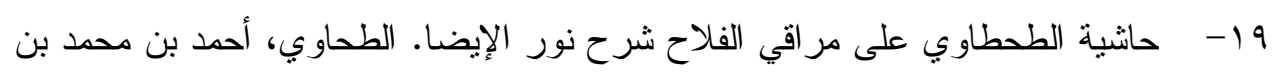

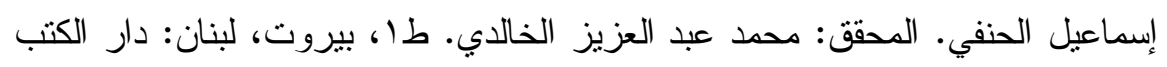

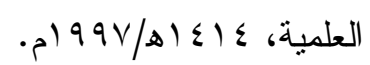

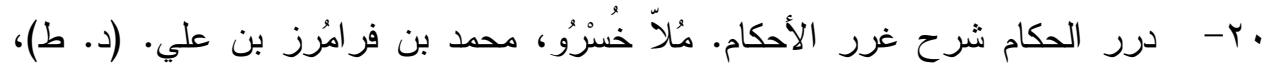

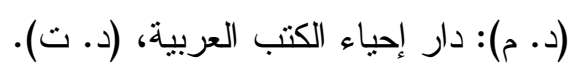

اب- الذخيرة. القرافي، أبو العباس شهاب الدين أحمد بن إدريس بن عبد الرحمن المالكي.

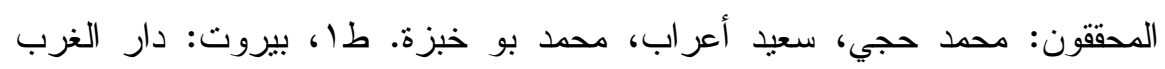

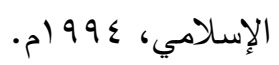


r T- رد المحتار على الدر المختار • ابن عابدين، محمد أمين بن عمر بن عبد العزيز عابدين

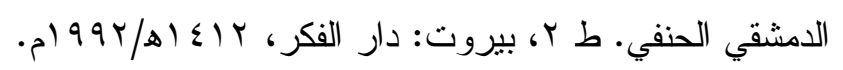

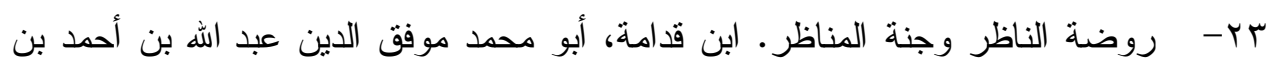

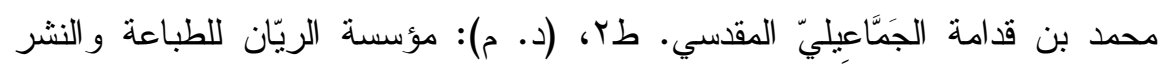

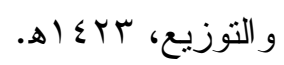

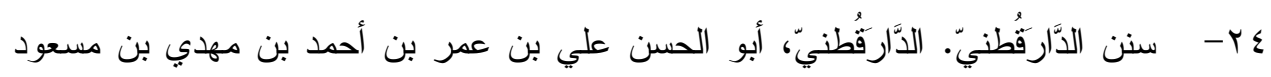

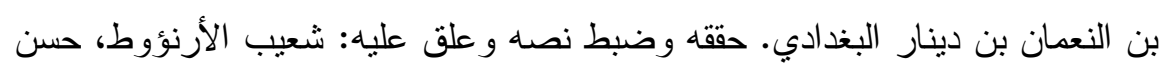

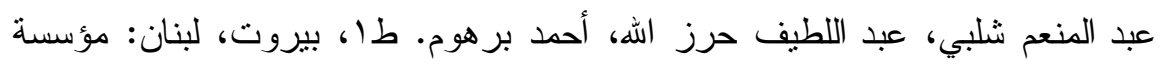

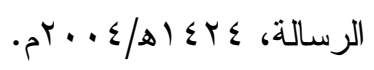

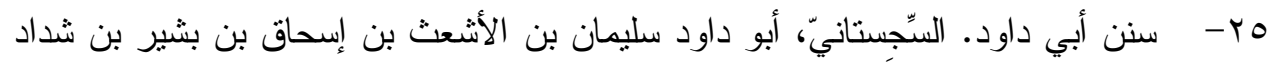

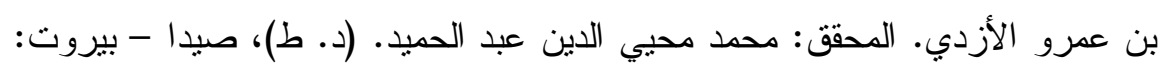

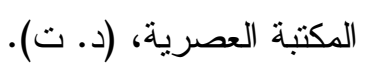

جr- سنن ابن ماجه. القَزوِيني، أبو عبد الهه محمد بن بزيد. المحقق: محمد فؤاد عبد الباقي.

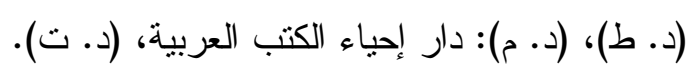

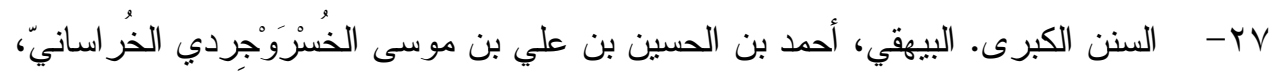

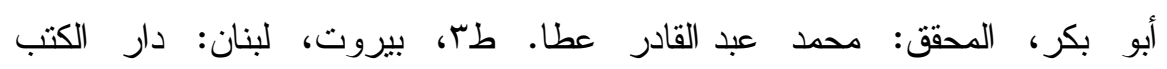

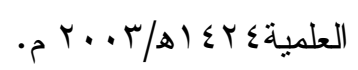

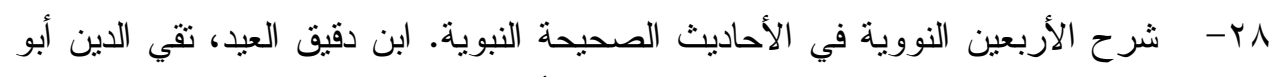

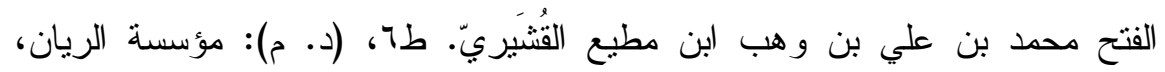

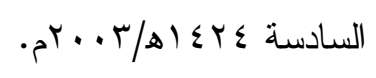

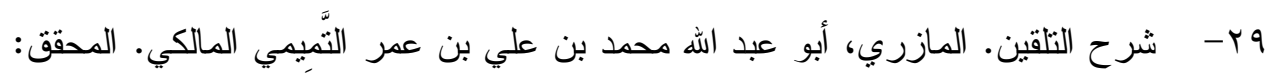

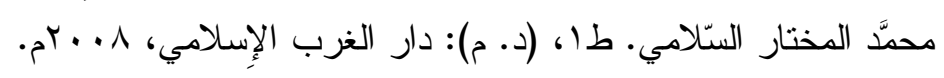

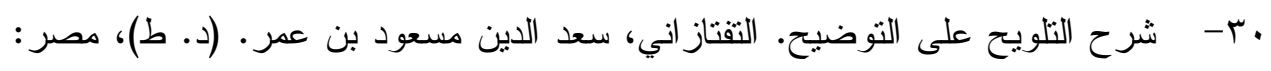

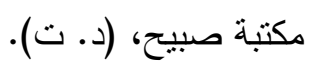

اب- شرح العددة في بيان مناسك الحج و العمرة. ابن تيمية، تقي الدين أبو العباس أحمد بن

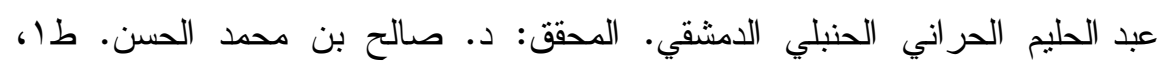

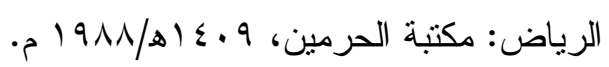


rr- صحيح البخاري. البخاري، محمد بن إسماعيل أبو عبد الله الجعفي. المحقق: محمد

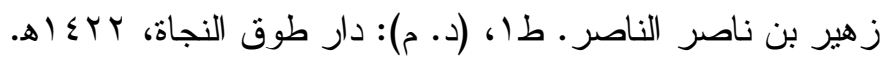

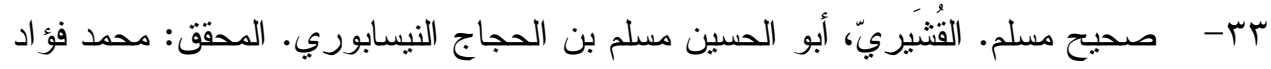

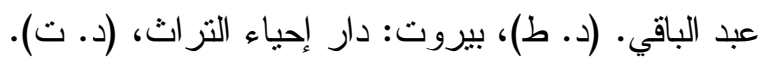

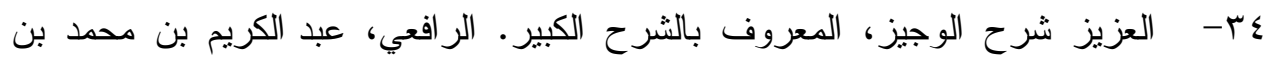

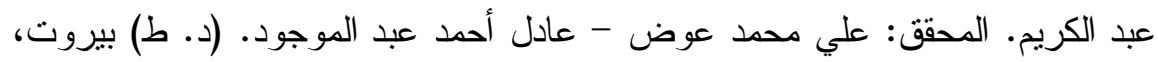
لبنان: دار الكتب العلمية، (د. ت).

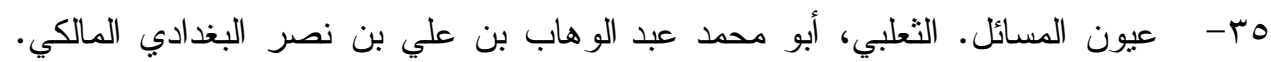

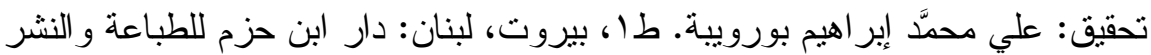

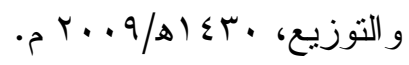

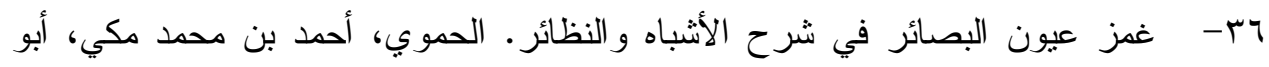

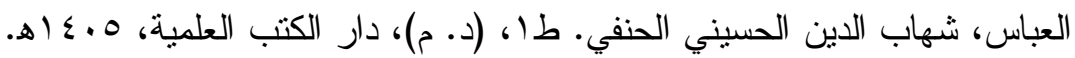
TV - الفتاوى الكبرى. ابن تيمية، تقي الدين أبو العباس أحمد بن عبد الحليم بن عبد السلام

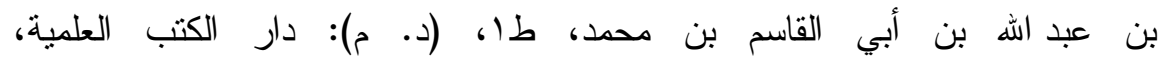
• $19 \wedge \mathrm{V} / \mathrm{s}) \leq \cdot \Lambda$

مب- الفتاوى الفقهية الكبرى. ابن حجر، أحمد بن محمد بن علي الهيثمي. جمعها: تلميذ ابن

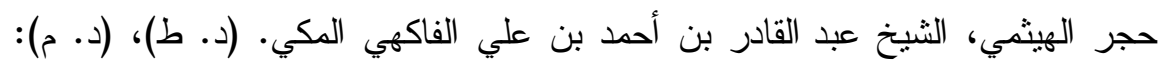
المكتبة الإسلامية، (د. تم). وب- فتح الباري شرح صحيح البخاري. ابن حجر العَنقلانيّ. رقم كتبه و أبو ابه وأحاديثه:

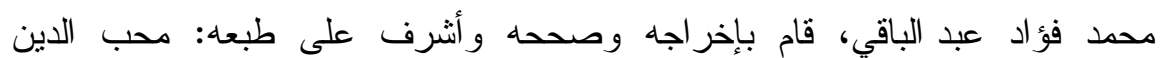

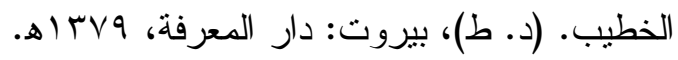

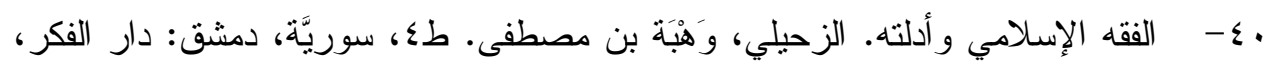

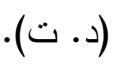
اءـ - فقه الأولويات دراسة في الضوابط. الوكيلي: محمد. طا، فيرجينيا: المعهد العالمي للفكر الإسلامي، 77 (1) اله. rع- فقه الأولويات في ظلال مقاصد الثريعة الإسلامية. الكربول، عبد السلام عيادة علي.

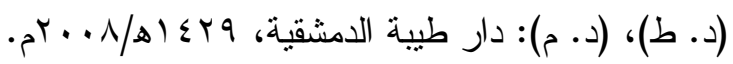


بـ - قو اعد الأحكام في مصالح الأنام. العز بن عبد السلام، أبو محمد عز الدين عبد العزيز

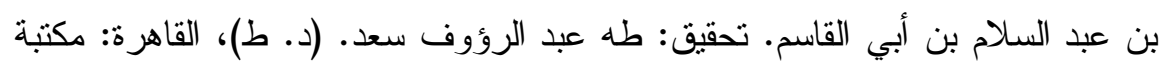

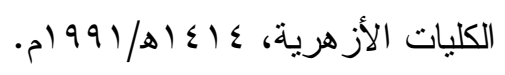

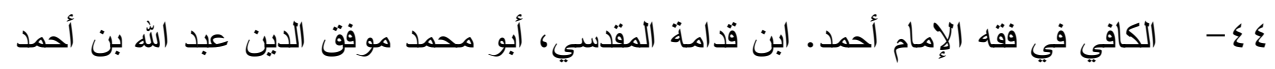

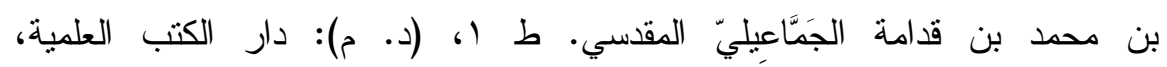

$$
\text { . } 1998 / 81 \leq 1 \leq
$$

0ـ- - الكتاب المصنف في الأحاديث و الآثار . ابن شيبة، أبو بكر عبد الله بن محمد بن إبر اهيم

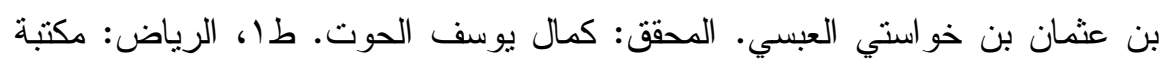

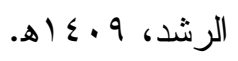

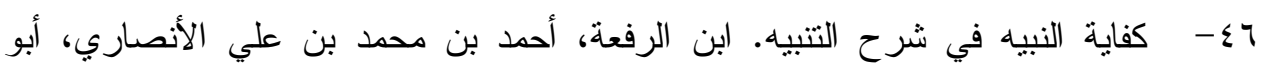

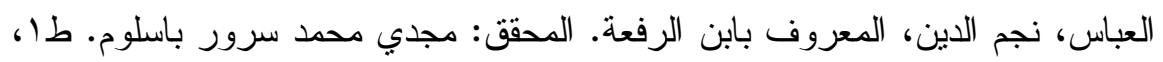

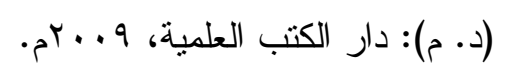

¿V

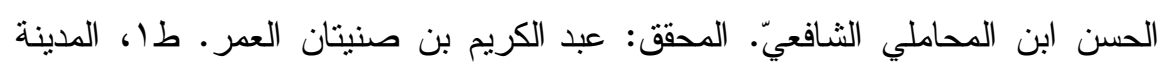

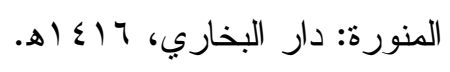

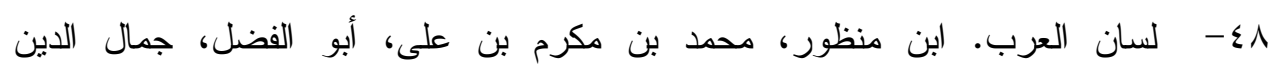

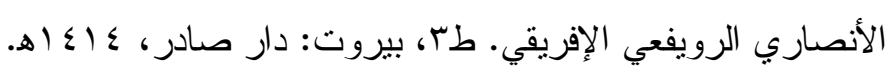

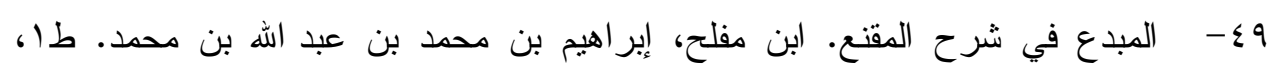

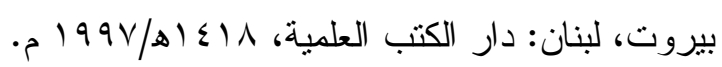

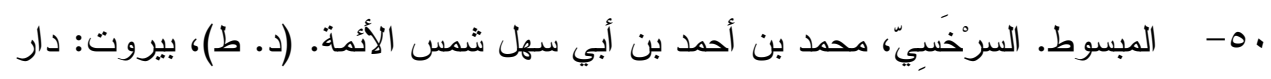

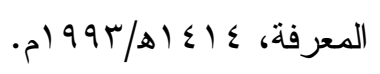
إ- مجمع الأنهر في شرح ملتقى الأبحر . داماد أفندي، عبد الرحمن بن محمد بن سليمان

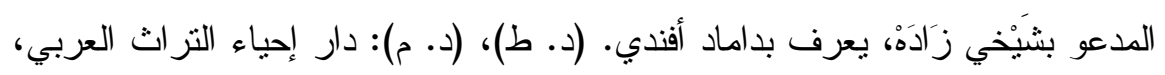

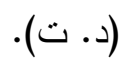

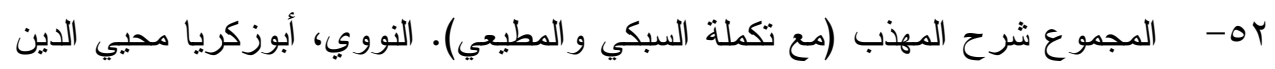

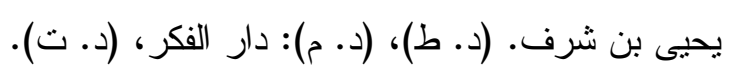


ro- المحرر في الققه على مذهب الإمام أحمد بن حنبل، ابن تيمية الحراني، عبد السلام بن

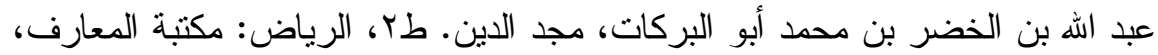
• $19 \wedge \leq / ه 1 \leq \cdot \varepsilon$ عـ- مدارج السالكين بين منازل إيالك نعبد و إياك نستعين. ابن قيم الجوزية، محمد بن أبي

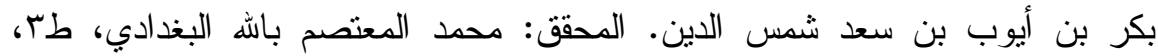

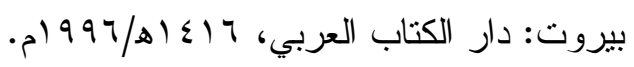
00- المدخل ابن الحاج الفاسي، أبو عبد اله محمد بن محمد بن محمد العبدري المالكي.

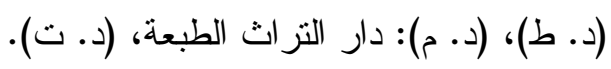

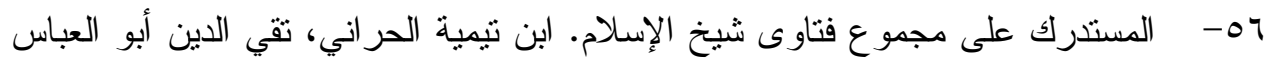

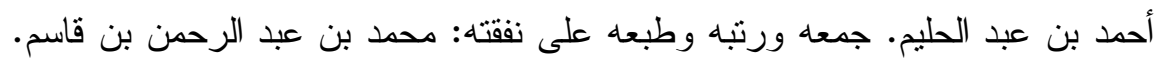

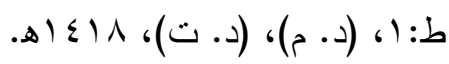

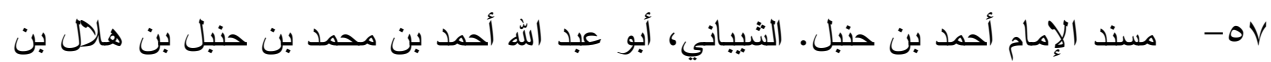

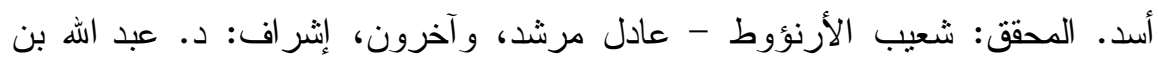

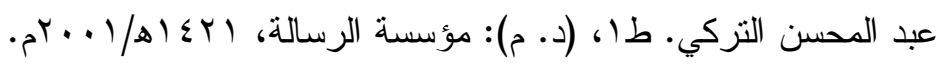

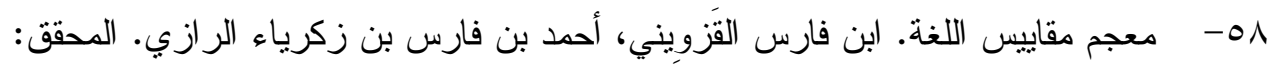

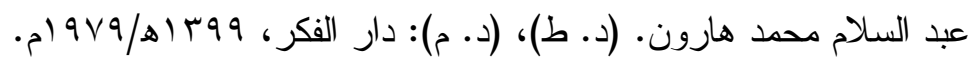

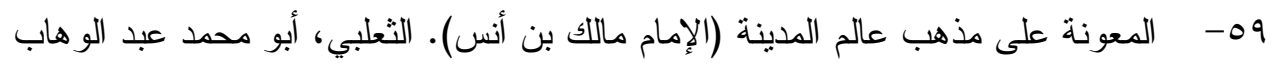

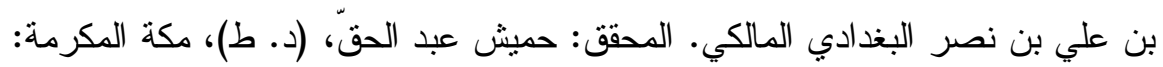

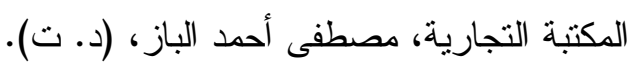

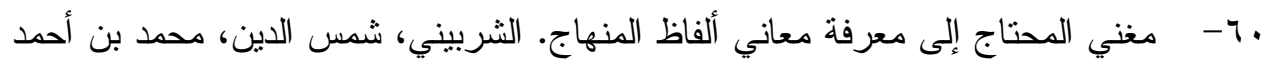

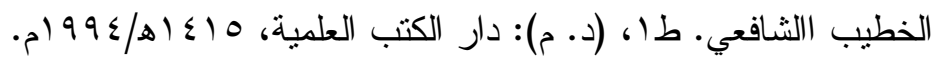

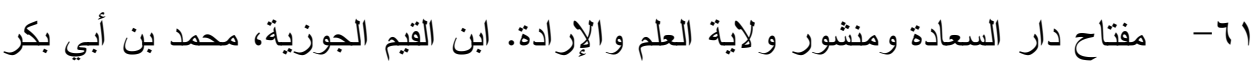

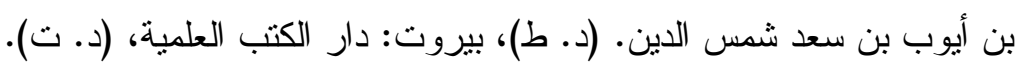

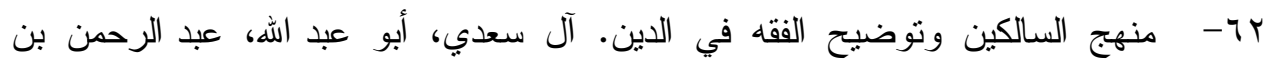

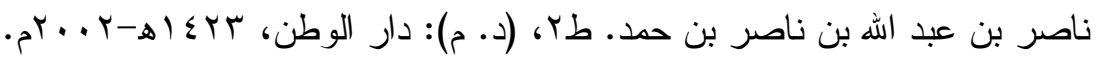

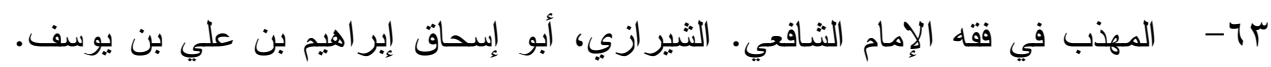
(د. ط)، (د. م): دار الكتب العلمية، (د. تم). 
ع ا- المغني. ابن قدامة المقدي، محمد موفق الدين عبد الله بن أحمد بن محمد الجَمَّاعِيليّ.

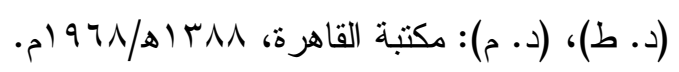

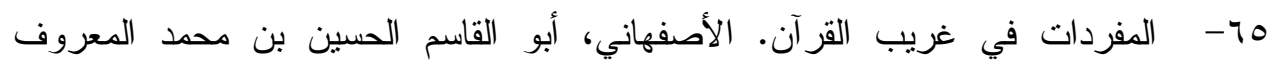

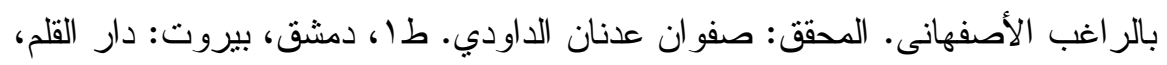

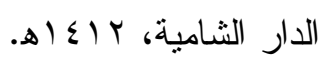

דا- مواهب الجليل في شرح مختصر خليل. الطر ابلسي، شمس الدين أبو عبد الله محمد بن

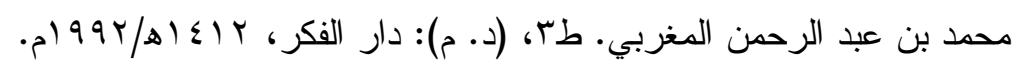

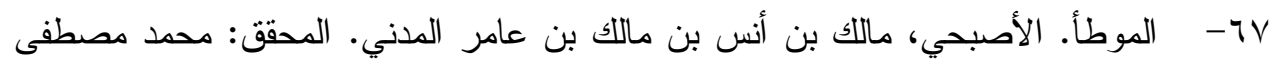
الأعظمي. طا، أبو ظبي، الإمارات: مؤسسة زايد بن سلطان آل نهيان للأعمال

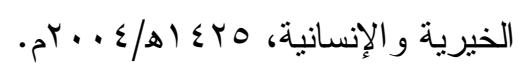

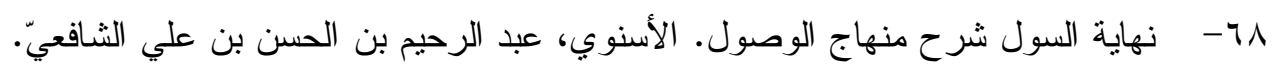

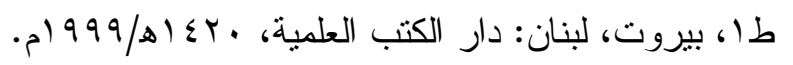

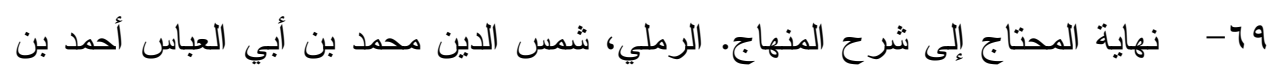

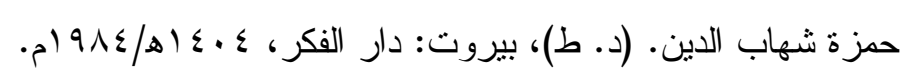

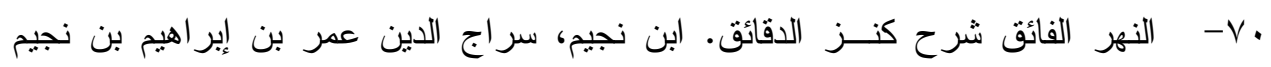

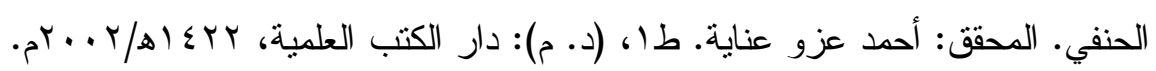

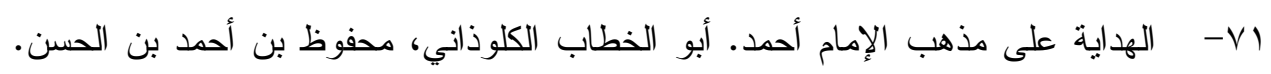

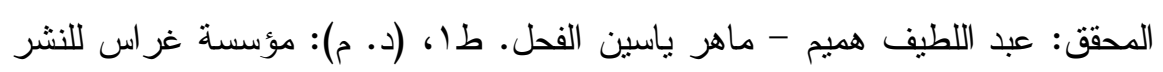

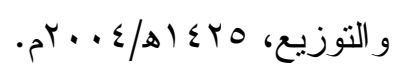

